\title{
Articles
}

\section{Coupling of FRET and Photoinduced Electron Transfer in Regioregular Silylene-Spaced Energy Donor-Acceptor-Electron Donor Copolymers}

\author{
Hsian-Wen Wang, ${ }^{\dagger}$ Mei-Yu Yeh, ${ }^{\dagger}$ Chih-Hsien Chen, ${ }^{\dagger, \ddagger}$ Tsong-Shin Lim, ${ }^{\S}$ \\ Wunshain Fann," and Tien-Yau Luh, ${ }^{*,+\perp}$ \\ Department of Chemistry, National Taiwan University, Taipei, Taiwan 106; Institute of Chemistry, \\ Academia Sinica, Taipei, Taiwan 115; Department of Physics, Tunghai University, \\ Taichung, Taiwan 407; Institute of Atomic and Molecular Sciences, Academia Sinica, \\ Taipei, Taiwan 106; and Shanghai Institute of Organic Chemistry, Chinese Academy of Sciences, \\ Shanghai, China 200032
}

Received January 13, 2008; Revised Manuscript Received February 2, 2008

\begin{abstract}
Two new silylene-spaced copolymers containing three kinds of different chromophores in regioregular manner were synthesized by rhodium-catalyzed hydrosilylation of a bisalkyne with a bis-silyl hydride. The photophysical and electrochemical properties of these polymers and the corresponding monomeric models were investigated. Time-resolved fluorescence spectroscopy has been employed for detailed kinetic analyses. The chromophores in these polymers have been shown to exhibit light harvesting to collect light energy, energy transfer, and efficient charge separation. The overall efficiencies involving both FRET and PET in these silylenespaced vinylarene copolymers can be up to $96 \%$.
\end{abstract}

\section{Introduction}

Natural photosynthetic process occurs in a nanometric assembly of chromophores that serve as antenna to induce energy transfer and launch a series of electron transfer processes that ultimately reach the reaction center which drives the reduction of various substrates. ${ }^{1,2}$ Research on artificial light harvesting and photoinduced electron transfer systems by assembling chromophores in dendrimers, ${ }^{3}$ functionalized polymers, ${ }^{4,5}$ Langmuir-Blodgett films, ${ }^{6}$ microspheres, ${ }^{7}$ monolayers, ${ }^{8}$ hydrogenbonded organic gels, ${ }^{9}$ and organic-inorganic hybrid materials ${ }^{10}$ have been extensive. However, integrations of light harvesting and electron transfer components into one system have been sporadically explored. ${ }^{11}$ To illustrate, supramolecular systems involving covalently bonded metal prophyrins, metal-free porphyrins and fullerene, and related approaches have been designed as models for photosynthetic processes. ${ }^{11}$ We recently reported a series of silylene-spaced divinylarene copolymers having alternating donor-acceptor chromophores that exhibit versatile photophysical properties including highly efficient intrachain energy or electron transfer. ${ }^{5}$ For example, effective photoinduced electron transfer from amino styrene moiety to anthracene chromophore has been found in copolymer $1 .{ }^{5 f}$ The silylene moiety in $\mathbf{1}$ can be considered as an insulating spacer, and no conjugative interactions between the $\pi$ systems and the silicon moiety may occur. ${ }^{5,12}$ The advantage of using silylenespaced divinylarene copolymers relies on the easy accessibility by regioselective hydrosilylation of a bisalkyne with a bis-silyl hydride. To illustrate, three different kinds of chromophores can

\footnotetext{
* Corresponding author.

† National Taiwan University.

Institute of Chemistry, Academia Sinica.

$\$$ Tunghai University.

"Institute of Atomic and Molecular Sciences, Academia Sinica.

${ }^{\perp}$ Chinese Academy of Sciences.
}

be selectively assembled into the polymeric backbone where sequential energy transfer has been observed. ${ }^{5 \mathrm{~d}}$ It is envisaged that regioselective incorporation of a donor chromophore as an antenna for absorbing light into $\mathbf{1}$ or the like could lead to an integrated polymeric archetype for light harvesting and electron transfer. We now wish to report the design, synthesis, and photophysical investigations of the integrated three-component systems in regioselective manner for investigating sequential energy and electron transfer.

\section{Results and Discussion}

Strategy. The general strategy is to design a polymer having an energy donor $\left(\mathbf{D}_{\mathbf{E}}\right)$, an electron donor $\left(\mathbf{E}_{\mathbf{d}}\right)$, and an acceptor (A) to collect fluorescence resonance energy from $\mathbf{D}_{\mathbf{E}}$ forming an excited state of $\mathbf{A}$, which will then accept an electron from $\mathbf{E}_{\mathbf{d}}$. The most important criterion is to have these chromophores $\mathbf{D}_{\mathbf{E}}, \mathbf{A}$, and $\mathbf{E}_{\mathbf{d}}$ in close proximity so that fluorescence resonance energy transfer (FRET) and electron transfer can take place efficiently because they are distance dependent. Hydrosilylation reaction of a bisalkyne with a bis-silyl hydride has been shown to be extremely efficient for the synthesis of silylene spaced divinylarene copolymers like $\mathbf{1}$ having different chromophores arranged in alternating manner. ${ }^{5}$ Thus, two different kinds of polymers 2 were designed in this investigation. Polymer 2a involved an energy transfer pair consisted of 4,4'-divinylbiphenyl $\left(\mathbf{D}_{\mathbf{E}}\right)$ and $4,4^{\prime}$-divinylstilbene (A) ${ }^{5 \mathrm{c}}$ It is known that amines may quench the fluorescence of a fluorophore by means of the photoinduced electron transfer (PET). ${ }^{13}$ Accordingly, bis-aniline moiety was employed as an $\mathbf{E}_{\mathbf{d}}$ locating next to an $\mathbf{A}$.

In a similar manner, the second system $\mathbf{2 b}$ was comprised of 4,4'-divinylbiphenyl and 9-vinylanthracene as the FRET pair which was coupled with an aza-crown ether moiety as an electron donor for the PET. As shown in Figure 1, the emission maximum of $\mathbf{5}$ matched well with the absorption maximum of 


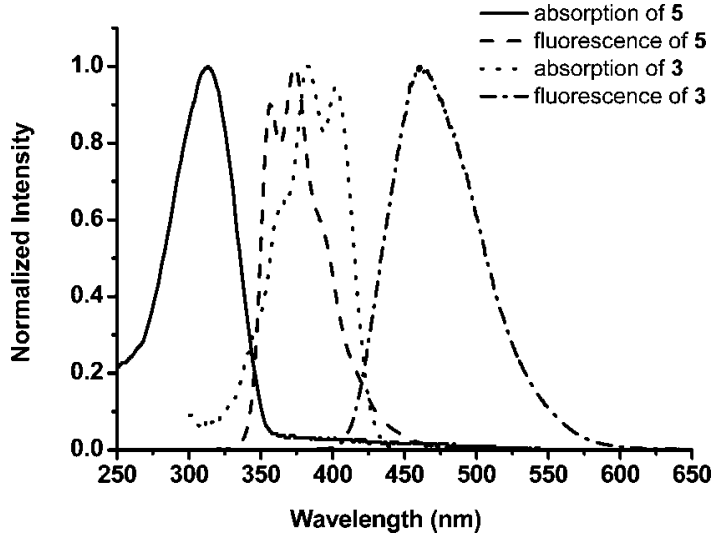

Figure 1. Normalized absorption spectrum of $\mathbf{5}$ (solid line) and $\mathbf{3}$ (dashed line) and emission spectra of $\mathbf{5}$ (dotted line, excitation wavelength: $310 \mathrm{~nm}$ ) and $\mathbf{3}$ (dash-dotted line, excitation wavelength: $382 \mathrm{~nm}$ ) in $\mathrm{CH}_{2} \mathrm{Cl}_{2}$.

Table 1. Photophysical Properties and Frontier Orbital Energies of $3,4,5,6$, and 7 in $\mathrm{CH}_{2} \mathrm{Cl}_{2}$

\begin{tabular}{ccccccc}
\hline & $\begin{array}{c}\lambda_{\max \text { abs }} \\
(\mathrm{nm})\end{array}$ & $\begin{array}{c}\lambda_{\max \mathrm{em}} \\
(\mathrm{nm})\end{array}$ & $\Phi^{a}$ & $\begin{array}{c}E_{\mathrm{Ox}}{ }^{b} \\
(\mathrm{eV})\end{array}$ & $\begin{array}{c}\mathrm{HOMO}^{c} \\
(\mathrm{eV})\end{array}$ & $\begin{array}{c}\mathrm{LUMO}^{d} \\
(\mathrm{eV})\end{array}$ \\
\hline $\mathbf{3}$ & 382 & 461 & 0.64 & 0.53 & -5.33 & -2.45 \\
$\mathbf{4}$ & 307 & 378 & 0.03 & 0.18 & -4.98 & -1.57 \\
$\mathbf{5}$ & 310 & 360,375 & 0.86 & 1.05 & -5.85 & -2.31 \\
$\mathbf{6}$ & 270 & 335 & 0.07 & 0.29 & -5.09 & -1.25 \\
$\mathbf{7}$ & 355 & 390,410 & 0.91 & 0.78 & -5.58 & -2.40
\end{tabular}

${ }^{a}$ Using coumarin 1 as a reference. ${ }^{b}$ Oxidation potentials determined by cyclic voltammetry using $0.1 \mathrm{M} \mathrm{Bu}_{4} \mathrm{NPF}_{6}$ as electrolyte with Pt working electrode, Pt wire counter electrode, and $\mathrm{Ag} / \mathrm{AgNO}_{3}$ reference electrode. ${ }^{c}$ Estimated by $E_{\mathrm{ox}} \mathrm{vs} \mathrm{Fc} / \mathrm{Fc}^{+} .{ }^{d}$ Estimated by $\mathrm{HOMO}$ and optical band gap from absorption spectra.

3. The photophysical properties and frontier orbital energies of the model compounds 3-7 containing these chromophores are outlined in Table 1.<smiles>CC=Cc1c2ccccc2c(C)c2ccccc12</smiles><smiles>CC[SiH2]C=Cc1ccc(N(C)C)cc1</smiles><smiles>C[SiH](C)/C=C/c1ccc(-c2ccc(/C=C/[SiH](C)C)cc2)cc1</smiles><smiles>C[SiH2]c1ccc(N(C)CCCN(C)c2ccc([SiH](C)C)cc2)cc1</smiles>

$$
5
$$

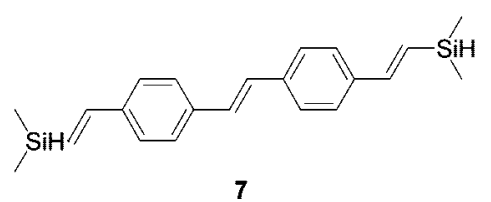

Synthesis. Monomer $\mathbf{3}$ was prepared by Heck reaction of $\mathbf{8}^{14}$ with trimethylvinylsilane (eq 1). Diamine 6 was prepared according to eq 1 . Bromination of $\mathbf{9}^{15}$ afforded the corresponding dibromide 10, which was treated with BuLi followed with chlorodimethylsilane to give $\mathbf{6}$ in $68 \%$ overall yield. Polymer 2a was synthesized regioselectively according to Scheme 1. Wittig-Horner reaction of $\mathbf{1 1}$ with $\mathbf{1 2}$ afforded $84 \%$ yield of 13. Sequential Sonogashira reaction of $\mathbf{1 3}$ upon treatment with

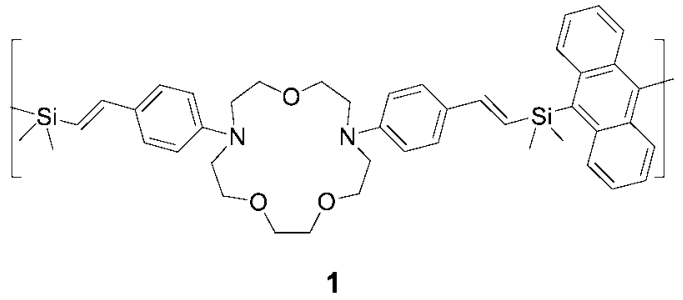

$$
\left.{ }_{-A}-S^{\prime}-D_{E}, S i-A-S^{\prime}-E_{d}-S i+\right\rceil_{n}
$$

2

a

$\mathrm{D}_{\mathrm{E}}$

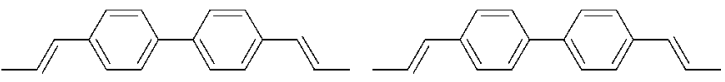

A
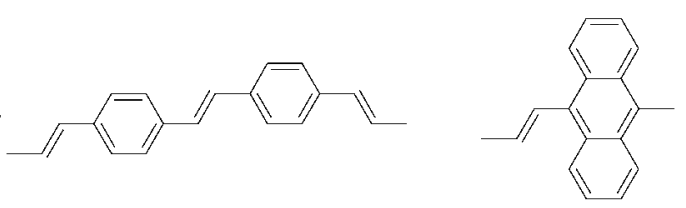

$E_{d}$<smiles>Cc1ccc(N(C)CCCN(C)c2ccc(C)cc2)cc1</smiles><smiles>C/C=C/c1ccc(N2CCOCCOCCN(c3ccc(/C=C/C)cc3)CCOCC2)cc1</smiles>

1 equiv of triisopropylsilylacetylene yielded 14, which was then allowed to react with trimethylsilylacetylene to afford $\mathbf{1 5}$ in $\mathbf{7 4 \%}$ overall yield. Selective removal of the trimethylsilyl group in 15 with base led to $81 \%$ yield of $\mathbf{1 6}$. Rhodium-catalyzed hydrosilylation of $5^{5 \mathrm{e}}$ with 2 equiv of $\mathbf{1 6}$ resulted in the formation of $\mathbf{1 7}$ in $66 \%$ yield. Desilylation of the TIPS group in $\mathbf{1 7}$ with TBAF furnished $\mathbf{1 8}$ in $90 \%$ yield. Hydrosilylation of 18 with $\mathbf{6}$ afforded the silylene-spaced polymer 2a consisting of three chromophores in a regioregular arrangement. The molar fraction of each chromophore in polymer $\mathbf{2 a}$ was 1 to 2 to 2 , corresponding to $\mathbf{D}_{\mathbf{E}}, \mathbf{A}$, and $\mathbf{E}_{\mathbf{d}}$, respectively.

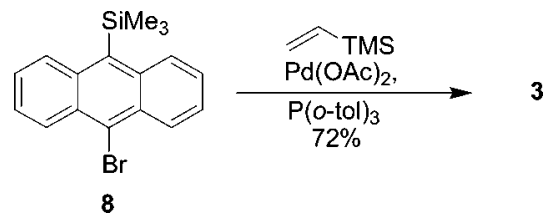<smiles>CN(CCCN(C)c1ccccc1)c1ccccc1</smiles>

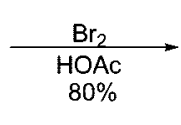

9

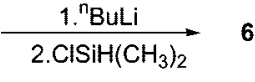<smiles>CN(CCCN(C)c1ccc(Br)cc1)c1ccc(Br)cc1</smiles>

10
$85 \%$ 
Scheme 1

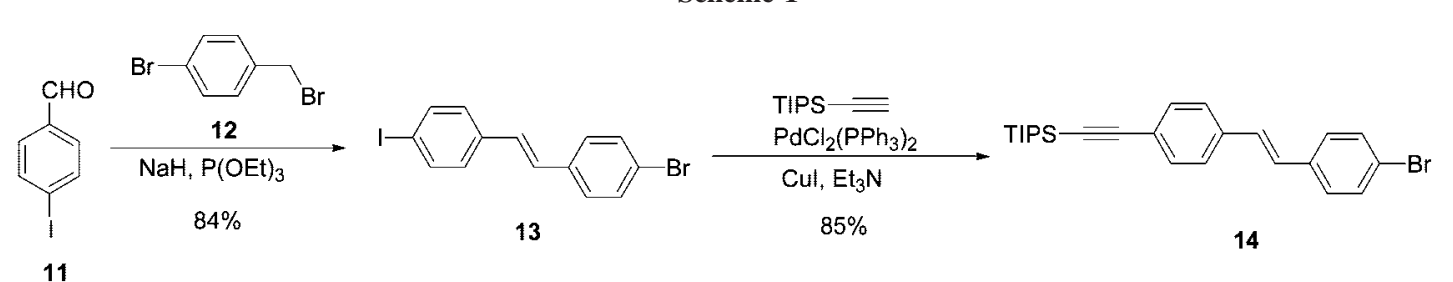

11

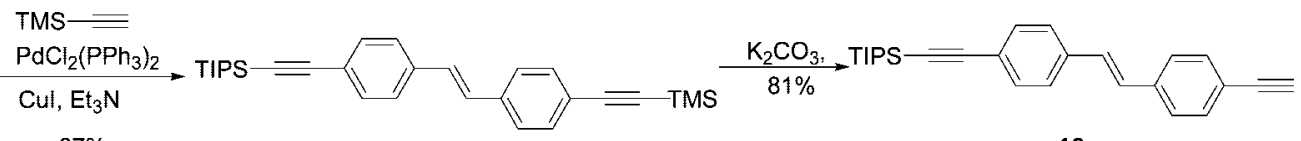

$87 \%$

15

16

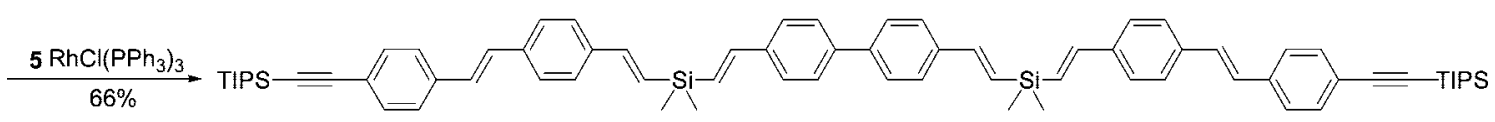

17

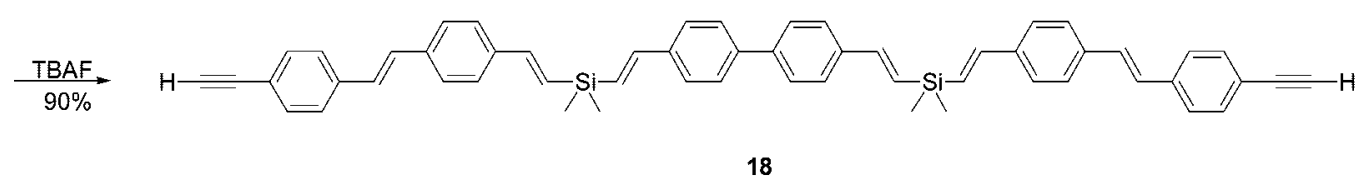

$\underset{\mathrm{Nal}}{\stackrel{\mathrm{RhCl}\left(\mathrm{PPh}_{3}\right)_{3}}{\longrightarrow}} 2 \mathrm{a}$

Scheme 2

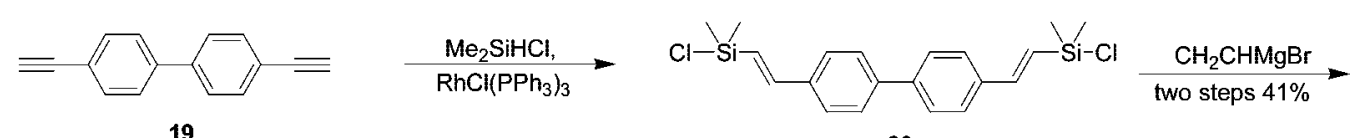

20

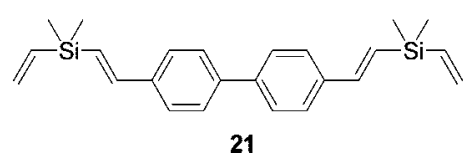

Treatment of bisalkyne $\mathbf{1 9}$ with chlorodimethylsilane in the presence of $\mathrm{RhCl}\left(\mathrm{PPh}_{3}\right)_{3}$ gave 20, followed by substitution with vinyl Grignard reagent to obtain 21 (Scheme 2).

Dibromoanthracene was treated with BuLi followed by chlorodimethylsilane to give $\mathbf{2 2}$ in $51 \%$ yield. Rhodiumcatalyzed hydrosilylation of bis-alkynyl-substituted aza-crown ether $\mathbf{2 3}$ with $\mathbf{2 2}$ gave $\mathbf{2 4}$ which underwent palladium-catalyzed Heck reaction with $\mathbf{2 1}$ furnished $\mathbf{2 b}$ with a regioregular combination of three different chromophores separated by dimethylsilylene moieties.

Photophysical Properties of Polymers. The absorption spectrum of polymer $\mathbf{2 a}$ in $\mathrm{CH}_{2} \mathrm{Cl}_{2}$ is shown in Figure $2 \mathrm{a}$. In comparison with the $\lambda_{\max }$ of the corresponding monomers 5-7, the absorption profile for $\mathbf{2} \mathbf{a}$ can be considered as the summation of the absorption of each of these monomeric chromophores. Thus, the absorption around $350 \mathrm{~nm}$ was attributed to divinylstilbene chromophore in $\mathbf{2 a}$, around $310 \mathrm{~nm}$ to the absorption of the divinylbiphenyl moiety, and around $270 \mathrm{~nm}$ as the absorption of the aminostyrene group. The emission spectra of $\mathbf{2 a}$ in different solvents are shown in Figure $2 b$. The quantum yields of the emission of $\mathbf{2 a}$ around $400 \mathrm{~nm}$ were solvent dependent (Table 2), and no emission due to divinylbiphenyl chromophore was observed. It is interesting to note that charge transfer band around $500 \mathrm{~nm}$ was observed when the measurements were taken in $\mathrm{CH}_{2} \mathrm{Cl}_{2}$ or THF. ${ }^{16}$ These results suggested that energy transfer was very efficient, and photoinduced electron transfer between the aminobenzene group $\left(\mathbf{E}_{\mathbf{d}}\right)$ and the divinylstilbene moiety (A) might readily take place in 2a.

The UV absorption and emission spectra for $\mathbf{2 a}$ were further examined by titration with $\mathrm{Zn}\left(\mathrm{ClO}_{4}\right)_{2}$ in $\mathrm{CH}_{2} \mathrm{Cl}_{2}$ (Figure 3). The intensities at $270 \mathrm{~nm}$ in the absorption spectra were decreased with the added zinc ion concentration. On the other hand, the emission intensities around $411 \mathrm{~nm}$ were increased with $\mathrm{Zn}^{2+}$ concentration. Diamine moiety in $\mathbf{2 a}$ is known to form chelation complex with metal ions. Chelation-enhanced fluorescence (CHEF) was indeed observed for $\mathbf{2 a}$ upon addition of $\mathrm{Zn}^{2+}$. These results further support the electron transfer process between the aminobenzene group $\left(\mathbf{E}_{\mathbf{d}}\right)$ and the divinylstilbene moiety (A) in $\mathbf{2 a}$.

The absorption and emission spectra (excitation at $310 \mathrm{~nm}$ ) of $\mathbf{2 b}$ are shown in Figure 4. The quantum yields were also solvent dependent, and the results are shown in Table 2 and Figure 4c. Similar to those observed for $\mathbf{2 a}$, the addition of $\mathrm{Pb}^{2+}$ also perturbed the absorption and emission profiles (Figure 4), presumably due to complexation with the crown ether moiety in $\mathbf{2 b}$. It is interesting to note that there was very weak emission arising from $\mathbf{D}_{\mathbf{E}}$ chromophore (4,4'-divinylbiphenyl).

Time-Resolved Spectroscopy. Femtosecond laser equipped with a streak camera was employed to measure the time-resolved 

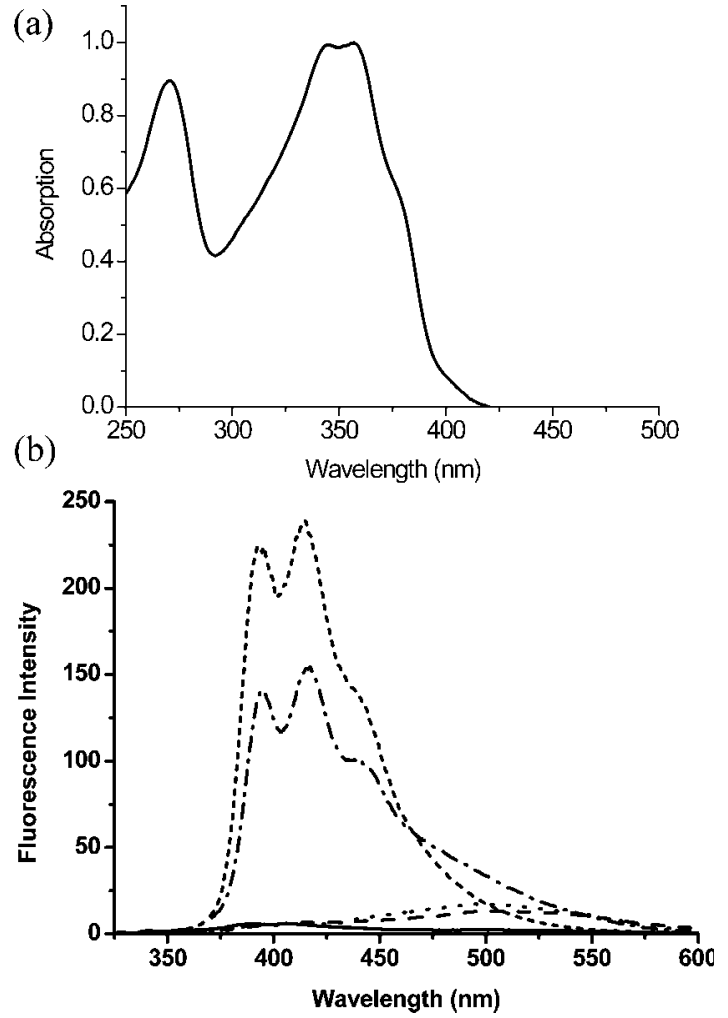

Figure 2. (a) Absorption spectrum of $2 \mathbf{a}\left(10^{-5} \mathrm{M}\right)$ in $\mathrm{CH}_{2} \mathrm{Cl}_{2}$. (b) Fluorescence spectra of $\mathbf{2 a}\left(10^{-5} \mathrm{M}, \lambda_{\mathrm{ex}}=310 \mathrm{~nm}\right)$ in $\mathrm{CH}_{3} \mathrm{CN}$ (solid line), $\mathrm{CH}_{2} \mathrm{Cl}_{2}$ (dashed line), THF (dotted line), toluene (dash-dotted line), and cyclohexane (short-dashed line).

Table 2. Quantum Yields ${ }^{a}$ of $2 \mathrm{a}$ and $2 \mathrm{~b}$ in Different Solvents

\begin{tabular}{cccccc}
\hline polymer & cyclohexane & toluene & THF & $\mathrm{CH}_{2} \mathrm{Cl}_{2}$ & $\mathrm{CH}_{3} \mathrm{CN}$ \\
\hline $\mathbf{2 a}$ & 0.643 & 0.438 & 0.065 & 0.064 & 0.026 \\
$\mathbf{2 b}$ & 0.417 & 0.167 & 0.066 & 0.065 &
\end{tabular}

${ }^{a}$ Quantum yield was obtained using coumarin-I in EtOAc as reference $(\Phi=0.99)$.

spectra of fluorescence quenching in copolymers $\mathbf{2 a}$ and $\mathbf{2 b}$. As discussed previously, both FRET between $\mathbf{D}_{\mathbf{E}}$ and A chromophores and PET between $\mathbf{E}_{\mathbf{d}}$ and $\mathbf{A}$ would take place. The two processes can be monitored by the fluorescence decay of chromophores in copolymers, and the rate constant and efficiency can be estimated comparing with the corresponding reference monomers.

As shown in Figure 4, there is residual emission from the donor chromophore divinylbiphenyl moiety. The fluorescence decay profiles of divinylbiphenyl moiety $\left(\mathbf{D}_{\mathbf{E}}\right)$ in copolymer $\mathbf{2 b}$ and the corresponding reference monomer $\mathbf{5}$ are shown in Figure 5 . The fluorescence decay lifetimes $\left(\tau_{\mathrm{E}}\right)$ were estimated by exponential curve fittings to give lifetimes $54 \mathrm{ps}$ for $\mathbf{D}_{\mathbf{E}}$ in $\mathbf{2 b}$ and $900 \mathrm{ps}$ for $\mathbf{5}$, and the energy transfer rate and efficiency were calculated by eqs 1 and 2 .

$$
\begin{gathered}
k_{\mathrm{E}}=\tau_{\mathrm{E}}^{-1}-k \\
\Phi_{\mathrm{E}}=k_{\mathrm{E}} / \tau_{\mathrm{E}}^{-1}
\end{gathered}
$$

where $\tau_{\mathrm{E}}$ is the fluorescence decay lifetimes of $\mathbf{D}_{\mathbf{E}}$ and $k$ is the reciprocal of the fluorescence lifetime of corresponding reference monomers (e.g., 5). ${ }^{17} \Phi_{\mathrm{E}}$ and $k_{\mathrm{E}}$ denote energy transfer efficiency and rate, respectively. The $k_{\mathrm{E}}$ and $\Phi_{\mathrm{E}}$ between $\mathbf{D}_{\mathrm{E}}$ and $\mathbf{A}$ moieties in copolymer $\mathbf{2 b}$ were thus calculated to be 1.7 $\times 10^{10} \mathrm{~s}^{-1}$ and 0.93 .

Unlike $\mathbf{2 b}$, FRET between $\mathbf{D}_{\mathbf{E}}$ and $\mathbf{A}$ in 2a was much more efficient than that in $\mathbf{2 b}$ (Figure 2b). The energy transfer from
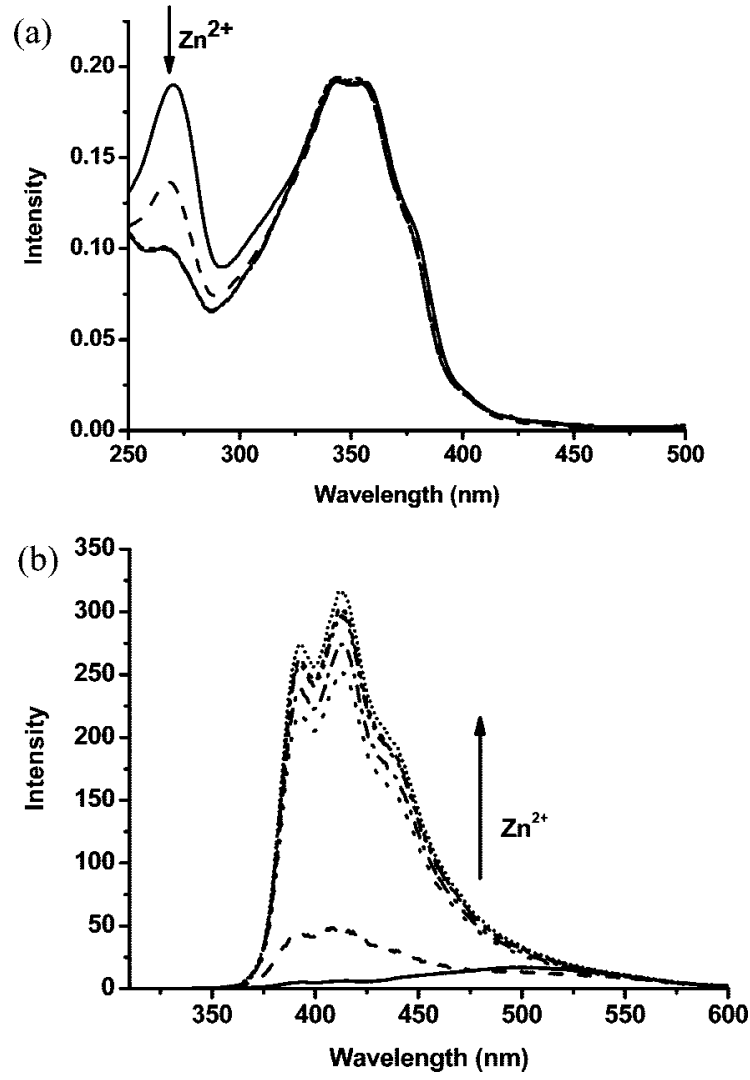

Figure 3. (a) Absorption and (b) emission spectra $\left(\lambda_{\mathrm{ex}}=310 \mathrm{~nm}\right)$ of $2 \mathrm{a}\left(1 \times 10^{-5} \mathrm{M}\right)$ in $\mathrm{CH}_{2} \mathrm{Cl}_{2}$ titrated with $\mathrm{Zn}\left(\mathrm{ClO}_{4}\right)_{2}$.

biphenyldivinyl moiety $\left(\mathbf{D}_{\mathbf{E}}\right)$ to divinylstilbene chromophore (A) in 2a was too fast to be measured by a streak camera with instrument limitation about 3 ps. As a result, the fluorescence decay lifetime of $\mathbf{D}_{\mathbf{E}}$ in $\mathbf{2 a}$ was assumed to be 3 ps. The rate constant $k_{\mathrm{E}}$ and quantum efficiency $\Phi_{\mathrm{E}}$ between $\mathbf{D}_{\mathbf{E}}$ and $\mathbf{A}$ moieties in 2a were estimated to be $3.3 \times 10^{11} \mathrm{~s}^{-1}$ and 0.99 , respectively. These results are outlined in Table 3 .

The PET in copolymers 2 was investigated by time-resolved spectra of fluorescence quenching monitoring at the emission of A. The charge transfer rate constant $k_{\mathrm{CS}}$ and charge-separation yield $\Phi_{\mathrm{CS}}$ were calculated according to eqs 3 and $4,{ }^{18}$ in which the $k_{\mathrm{s}}$ is the reciprocal of the fluorescence lifetime of corresponding reference monomers ${ }^{17}$ and $\tau_{\mathrm{CS}}$ is the fluorescence decay lifetime of $\mathbf{A}$ in copolymers.

$$
\begin{aligned}
& k_{\mathrm{CS}}=\tau_{\mathrm{CS}}{ }^{-1}-k_{\mathrm{s}} \\
& \Phi_{\mathrm{CS}}=k_{\mathrm{CS}} / \tau_{\mathrm{CS}}{ }^{-1}
\end{aligned}
$$

Figure 6 shows the fluorescence decay profiles of divinylstilbene chromophore (A) in 2a and corresponding reference monomer 7. Biexponential fitting was employed to obtain lifetimes of divinylstilbene chromophore (A) to be 28 ps (67\%) and $412 \mathrm{ps}(33 \%)$, and the fluorescence lifetime of 7 is 1050 ps. According to eqs 3 and 4 , the $k_{\mathrm{CS}}$ and $\Phi_{\mathrm{CS}}$ were calculated, and the results are summarized in Table 3 . The fluorescence decay profiles of the 10-vinylanthracene chromophore (A) in 2b is shown in Figure 7. The fluorescence decay lifetimes $\left(\tau_{\mathrm{E}}\right)$ were estimated by exponential fittings as 22 ps (65\%) and 194 ps (28\%) for 10-vinylanthracene chromophore (A) in $\mathbf{2 b}$, and the fluorescence lifetime of $\mathbf{3}$ is $12 \mathrm{~ns}$ measured by single photon counting. The charge-transfer rate constant $k_{\mathrm{CS}}$ and the corresponding charge-separation yield $\Phi_{\mathrm{CS}}$ 's were calculated according to eqs 3 and 4 , and the results are listed in Table 3 .

As can be seen from Table 3, two different fluorescence 

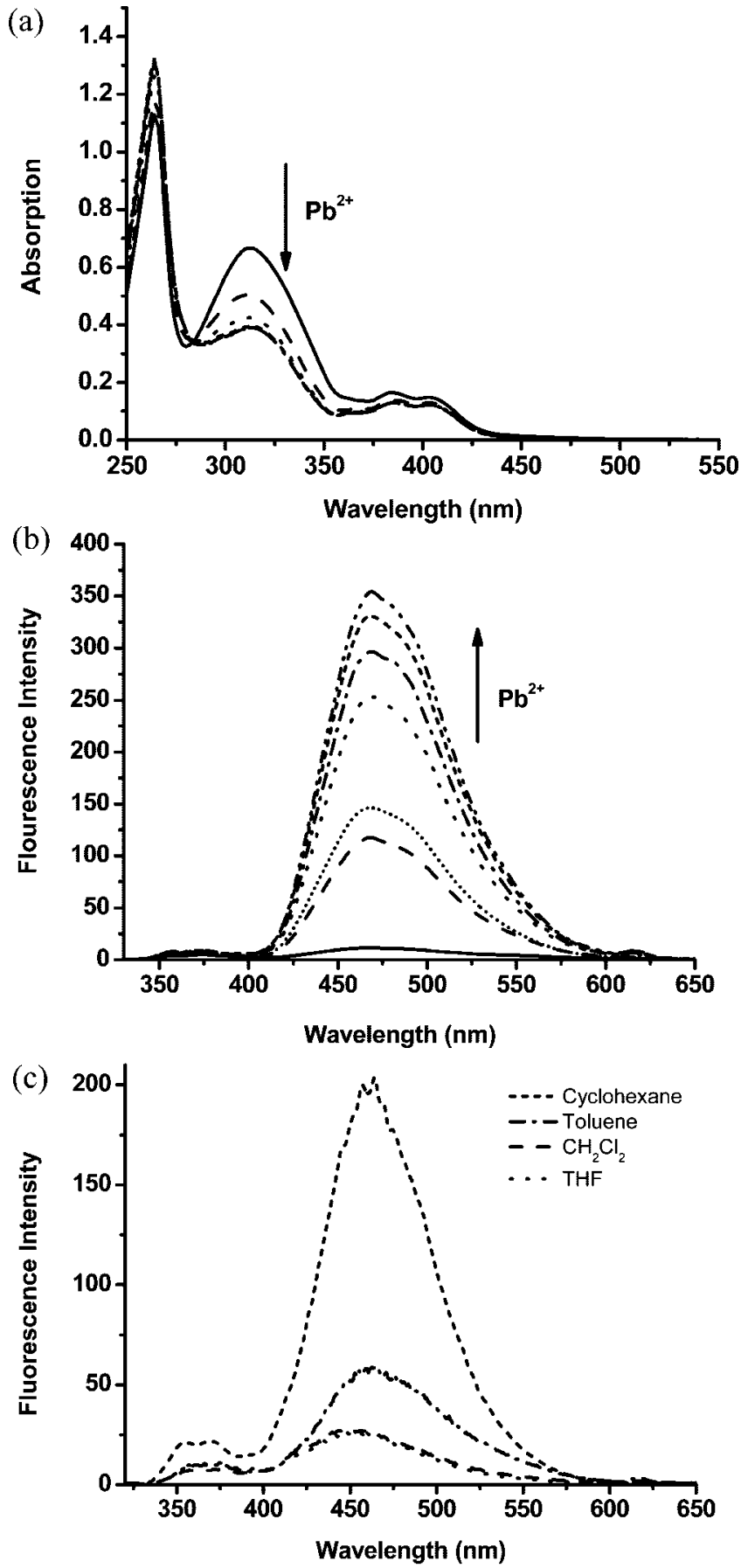

Figure 4. (a) Absorption and (b) emission spectra $\left(\lambda_{\mathrm{ex}}=311 \mathrm{~nm}\right)$ of $2 \mathbf{b}$ in $\mathrm{CH}_{2} \mathrm{Cl}_{2}\left(10^{-5} \mathrm{M}\right)$ titrated with $\mathrm{Pb}^{2+}$. (c) Emission spectra of $\mathbf{2 b}$ $\left(10^{-5} \mathrm{M}\right)$ in different solvents.

lifetimes were obtained for each of $\mathbf{2} \mathbf{a}$ and $\mathbf{2 b}$. Similar behavior was observed in related systems. ${ }^{5 \mathrm{f}, \mathrm{h}}$ This observation suggested that there might be two different modes of electron transfer processes in these polymers. The shorter lifetimes $\tau_{1}$ 's, the faster $k_{\mathrm{CS}}$ 's, and the higher charge separation yields $\Phi_{\mathrm{CS}}$ may arise from the interaction of two neighboring chromophores separated by a silylene moiety. It is interesting to note that the presence of the geminal dimethyl group on silicon might dictate the relative conformation of the remaining substituents on this silicon atom. Indeed, it has recently been shown that the Thorpe-Ingold effect might play an important role on the photophysics of silylene-spaced divinylarene copolymers. ${ }^{5 \mathrm{~g}, \mathrm{~h}}$ Accordingly, the silylene-spaced divinylarene copolymers are highly folded. ${ }^{5}$ As such, the two non-neighboring chromophores

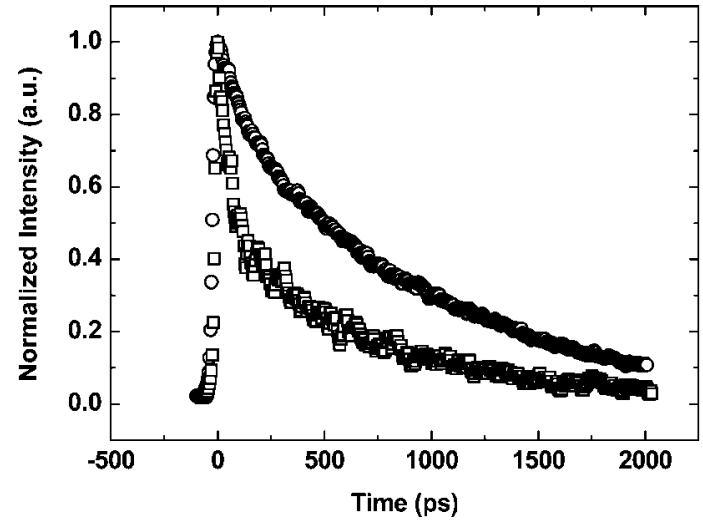

Figure 5. Time-resolved fluorescence decay of divinylbiphenyl chromophore $\left(\mathbf{D}_{\mathbf{E}}\right)$ in $\mathbf{2 b}$ (open square) and the corresponding monomeric reference 5 (open square) in $\mathrm{CH}_{2} \mathrm{Cl}_{2}$ monitoring at $360-380 \mathrm{~nm}\left(\lambda_{\mathrm{ex}}=\right.$ $300 \mathrm{~nm})$.

Table 3. Fluorescence Lifetime $(\tau)$, Rate Constant $\left(k_{\mathrm{CS}}\right)$, and Yield $\left(\Phi_{\mathrm{CS}}\right)$ of $2 \mathrm{a}$ and $2 \mathrm{~b}$ in $\mathrm{CH}_{2} \mathrm{Cl}_{2}$ at Ambient Temperature

\begin{tabular}{|c|c|c|c|c|c|c|c|}
\hline & \multicolumn{3}{|c|}{ energy transfer } & \multicolumn{3}{|c|}{ electron transfer } & \multirow[b]{2}{*}{$\Phi_{\text {total }^{a}}$} \\
\hline & $\begin{array}{c}\tau_{\mathrm{E}} \\
(\mathrm{ps})\end{array}$ & $\begin{array}{c}k_{\mathrm{E}} \\
\left(\mathrm{s}^{-1}\right)\end{array}$ & $\Phi_{\mathrm{E}}$ & $\begin{array}{c}\tau_{\mathrm{E}} \\
(\mathrm{ps})\end{array}$ & $\begin{array}{c}k_{\mathrm{CS}} \\
\left(\mathrm{s}^{-1}\right)\end{array}$ & $\Phi_{\mathrm{CS}}$ & \\
\hline \multirow[t]{2}{*}{$2 \mathbf{a}$} & $3^{b}$ & $3.3 \times 10^{11}$ & 0.99 & $28(67 \%)$ & $3.5 \times 10^{10}$ & 0.97 & 0.96 \\
\hline & & & & $412(33 \%)$ & $0.37 \times 10^{9}$ & 0.57 & 0.56 \\
\hline \multirow[t]{2}{*}{$2 \mathbf{b}$} & 54 & $1.7 \times 10^{10}$ & 0.93 & $22(67 \%)$ & $4.54 \times 10^{10}$ & 0.99 & 0.92 \\
\hline & & & & $194(33 \%)$ & $5.07 \times 10^{9}$ & 0.98 & 0.91 \\
\hline
\end{tabular}

${ }^{a} \Phi_{\text {total }}$ is the total efficiency from energy transfer to electron transfer. It can be obtained by multiplying $\Phi_{\mathrm{E}}$ and $\Phi_{\mathrm{CS}}{ }^{b}$ The lifetime was obtained by the limitation of instrument.

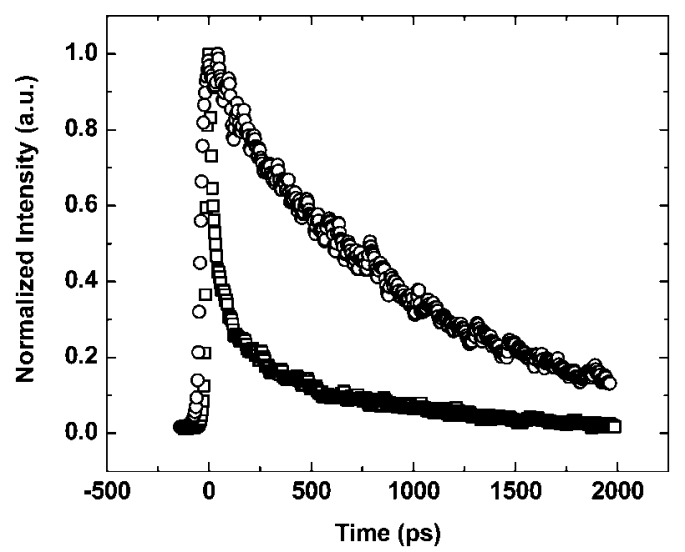

Figure 6. Time-resolved fluorescence decay of $\mathbf{A}$ in copolymer $\mathbf{2 a}$ (open square) and corresponding monomer 7 (open circle) in $\mathrm{CH}_{2} \mathrm{Cl}_{2}$ monitoring at $410-420 \mathrm{~nm}\left(\lambda_{\mathrm{ex}}=300 \mathrm{~nm}\right)$.

might meet each other through space. Slower rates might be expected from the through-space electron transfer between nonneighboring donor aminostyrene chromophore and the acceptor moiety in $\mathbf{2 a}$ or $\mathbf{2 b}$.

\section{Conclusions}

It is now well documented that the silylene-spaced copolymers exhibit a variety of fascinating photophysical properties. ${ }^{5}$ These copolymers are conveniently synthesized by rhodiumcatalyzed hydrosilylation of a bisalkyne with a bis-silyl hydride. The silylene moiety has provided an insulating tetrahedral spacer between two conjugated moieties. The emission wavelength can thus be well-adjusted, and the photophysical properties of polymers can be readily tuned. In addition, because of the presence of alkyl substituents on silicon which may increase the chain flexibility, the polymers may be more soluble in 


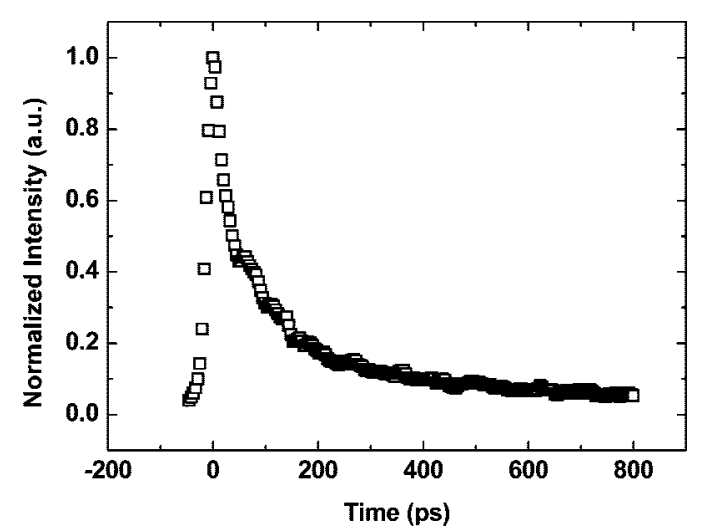

Figure 7. Time-resolved fluorescence decay of $\mathbf{A}$ in copolymer $\mathbf{2 b}$ (open square) monitoring at $460-480 \mathrm{~nm}\left(\lambda_{\mathrm{ex}}=300 \mathrm{~nm}\right)$.

organic solvent and therefore more processable. Since the silylene moiety has tetrahedral structure, the silylenechromophore copolymer may be highly folded. The distance between two neighboring chromophores separated by a silylene moiety (e.g., 2) xptk;1would be relatively short so that the chromophores in these polymers can exhibit light harvesting to collect light energy, energy transfer, and efficient charge separation. The overall efficiencies involving both FRET and PET in these silylene-spaced vinylarene copolymers can be up to $96 \%$.

\section{Experimental Section}

General. High-resolution mass spectrometric measurements were obtained from Jeol-JMS-700 mass spectrometry using FAB method in 3-nitrobenzyl alcohol matrix. Gel permeation chromatography (GPC) was performed on a Waters GPC machine using an isocratic HPLC pump (1515) and a refractive index detector (2414). THF was used as the eluent (flow rate $1 \mathrm{~mL} / \mathrm{min}$ ). Waters Styragel HR2, HR3, HR3, and HR4 $(7.8 \times 300 \mathrm{~mm})$ columns were employed for molecular weight determination, and polystyrenes were used as standard $\left(M_{\mathrm{n}}\right.$ values ranging from 375 to $\left.3.5 \times 10^{6}\right)$. Absorption spectra were measured with a Hitachi U-3310 spectrophotometer and emission spectra with a Hitachi F-4500 fluorescence spectrophotometer. The quantum yield was obtained using coumarin-I in EtOAc as reference $(\Phi=0.99)$. In time-resolved fluorescence experiments, a mode-locked Ti:sapphire laser (wavelength: $900 \mathrm{~nm}$; repetition rate: $76 \mathrm{MHz}$; pulse width: $<200 \mathrm{fs}$ ) passed through an optical parametric amplifier. The fluorescence of sample was reflected by a grating (150 grooves/mm; BLZ: $500 \mathrm{~nm})$ and detected by an optically triggered streak camera (Hamamatsu C5680) with a time resolution of about 0.3 ps. Oxidation potentials were determined by cyclic voltammetry using $0.1 \mathrm{M} \mathrm{Bu}_{4} \mathrm{NPF}_{6}$ as electrolyte with $\mathrm{Pt}$ working electrode, $\mathrm{Pt}$ wire as counter electrode, and $\mathrm{Ag} / \mathrm{AgNO}_{3}$ as reference electrode. Samples of $1 \mathrm{mM}$ solution were prepared in dry $\mathrm{CH}_{2} \mathrm{Cl}_{2}$. $\mathrm{HOMO}$ was estimated by $E_{\mathrm{ox}} \mathrm{vs} \mathrm{Fc} /$ $\mathrm{Fc}^{+}$, and LUMO was estimated by HOMO and optical band gap from the absorption spectra. Monomers $4,{ }^{5 f} 5,{ }^{5 e}$ and $7^{5 a}$ were prepared according to literature procedures.

(10-Bromoanthracen-9-yl)trimethylsilane (8). A solution of $n$-BuLi in hexane $(6.0 \mathrm{~mL}$ of $2.5 \mathrm{M}$ solution, $14.9 \mathrm{mmol})$ was added dropwise to a suspension of 9,10-dibromoanthracene (5.00 g, 14.9 $\mathrm{mmol})$ in THF $(400 \mathrm{~mL})$ at $-78^{\circ} \mathrm{C}$. The mixture was stirred at $-78^{\circ} \mathrm{C}$ for $15 \mathrm{~min}$. Chlorotrimethylsilane $(2.77 \mathrm{~g}, 25.5 \mathrm{mmol})$ was added dropwise at $-78^{\circ} \mathrm{C}$, and the mixture was allowed to warm gradually to room temperature (rt) and stirred for $8 \mathrm{~h} . \mathrm{NaHCO}_{3}$ solution was added, and the organic layer was separated. The aqueous layer was extracted with ether, the combined organic solution was dried $\left(\mathrm{MgSO}_{4}\right)$ and evaporated in vacuo, and the residue was passed through a short column of silica gel (hexane) to give 8 (3.20 g, $65 \%)$; mp $74-75{ }^{\circ} \mathrm{C}$. IR $(\mathrm{KBr}): v 3079,3028$, 2952, 2895, 2867, 1440, 1419, 1384, 1306, 1268, 1253, 1230, 920, $875,837,770,743,654 \mathrm{~cm}^{-1}$. ${ }^{1} \mathrm{H}$ NMR $\left(400 \mathrm{MHz}, \mathrm{CDCl}_{3}\right): \delta$ $0.72(\mathrm{~s}, 9 \mathrm{H}), 7.48-7.60(\mathrm{~m}, 4 \mathrm{H}), 8.44(\mathrm{~d}, J=8.8 \mathrm{~Hz}, 2 \mathrm{H}), 8.64$ $(\mathrm{d}, J=8.9,2 \mathrm{H}) .{ }^{13} \mathrm{C} \mathrm{NMR}\left(100 \mathrm{MHz}, \mathrm{CDCl}_{3}\right): \delta 4.6,124.8,126.3$, 126.6, 128.8, 129.0, 130.2, 137.1, 137.6. HRMS (FAB) $\left(\mathrm{M}^{+}\right.$, $\mathrm{C}_{17} \mathrm{H}_{17}{ }^{79} \mathrm{BrSi}$ ): calcd: 328.0283 ; found: 328.0279 .

10-(Trimethylsilyl)-9-(E-2-(trimethylsilyl)vinyl)anthracene (3). Under nitrogen, a mixture of $8(1.65 \mathrm{~g}, 5.0 \mathrm{mmol})$, trimethylvinylsilane (1.0 mg, $10.0 \mathrm{mmol})$, and dried DMF $(15.0 \mathrm{~mL})$ in a Schlenk flask was added $\mathrm{Pd}(\mathrm{OAc})_{2}(90 \mathrm{mg}, 0.4 \mathrm{mmol}), \mathrm{P}(o-\mathrm{Tol})_{3}$ $(60 \mathrm{mg}, 0.2 \mathrm{mmol})$, and dried $\mathrm{NEt}_{3}(6.0 \mathrm{~mL})$. The mixture was stirred at $70{ }^{\circ} \mathrm{C}$ for $36 \mathrm{~h}$. After cooling to rt, the mixture was poured into $\mathrm{H}_{2} \mathrm{O}$, extracted with $\mathrm{CH}_{2} \mathrm{Cl}_{2}$. The organic layer was dried $\left(\mathrm{MgSO}_{4}\right)$ and evaporated in vacuo to give the residue which was passed through a short column of silica gel (hexane) $(1.25 \mathrm{~g}, 72 \%)$. IR (KBr): $v$ 3076, 2953, 2895, 1511, 1439, 1401, 1249, 993, 935, 867, 839, 779, 769, 725, 692, $665 \mathrm{~cm}^{-1}$. ${ }^{1} \mathrm{H}$ NMR (400 MHz, $\left.\mathrm{CDCl}_{3}\right): \delta 0.33(\mathrm{~s}, 9 \mathrm{H}), 0.70(\mathrm{~s}, 9 \mathrm{H}), 6.32(\mathrm{~d}, J=19.6 \mathrm{~Hz}, 1 \mathrm{H})$, 7.43-7.46 (m, $4 \mathrm{H}), 7.69(\mathrm{~d}, J=19.6 \mathrm{~Hz}, 1 \mathrm{H}), 8.28-8.31(\mathrm{~m}, 2$ $\mathrm{H}), 8.42-8.44(\mathrm{~m}, 2 \mathrm{H}) .{ }^{13} \mathrm{C} \mathrm{NMR}\left(100 \mathrm{MHz}, \mathrm{CDCl}_{3}\right): \delta-1.1,4.6$, 124.2, 124.4, 126.9, 128.3, 129.1, 135.3, 136.8, 138.3, 141.0, 141.1. HRMS (FAB) $\left(\mathrm{M}^{+}, \mathrm{C}_{22} \mathrm{H}_{28} \mathrm{Si}_{2}\right)$ : calcd: 348.1730; found: 348.1734 .

2,6-Bis(4-dibromophenyl)-2,6-diazaheptane (10). A solution of $\mathrm{Br}_{2}(6.4 \mathrm{~g}, 40 \mathrm{~mol})$ in HOAc $(120 \mathrm{~mL})$ was added into a mixture of $9^{15}(5.09 \mathrm{~g}, 20 \mathrm{mmol}), \mathrm{HOAc}(80 \mathrm{~mL})$, and $\mathrm{I}_{2}$ (trace) cooled in an ice bath. The mixture was then refluxed for $2 \mathrm{~h}$. After cooling to $\mathrm{rt}$, the mixture was poured into water and separated. The aqueous layer was extracted with ether $(3 \times 150 \mathrm{~mL})$, and the combined organic layer was washed with brine, water, and dried $\left(\mathrm{MgSO}_{4}\right)$. The solvent was removed in vacuo to give the residue which was purified by flash chromatography using hexane as an eluent to afford 10 (6.59 g, 80\%); mp 70-71 ${ }^{\circ} \mathrm{C}$. IR (KBr): v 2938, 2868, 2815, 1634, 1593, 1499, 1373, 1311, 1291, 1192, 1140, 1111, 1078, 988, $806 \mathrm{~cm}^{-1} .{ }^{1} \mathrm{H} \mathrm{NMR}\left(400 \mathrm{MHz}, \mathrm{CDCl}_{3}\right): \delta 1.84$ (quint, $J=7.1 \mathrm{~Hz}$, $2 \mathrm{H}), 2.89(\mathrm{~s}, 6 \mathrm{H}), 3.32(\mathrm{t}, J=7.1 \mathrm{~Hz}, 4 \mathrm{H}), 6.54(\mathrm{~d}, J=8.6 \mathrm{~Hz}$, $4 \mathrm{H}), 7.27$ (d, $J=8.6 \mathrm{~Hz}, 4 \mathrm{H}) .{ }^{13} \mathrm{C} \mathrm{NMR}\left(100 \mathrm{MHz}, \mathrm{CDCl}_{3}\right): \delta$ 24.2, 38.7, 50.4, 107.9, 113.6, 131.3, 147.5. HRMS (EI) $\left(\mathrm{C}_{17} \mathrm{H}_{20}{ }^{79} \mathrm{Br}_{1}{ }^{81} \mathrm{Br}_{1} \mathrm{~N}_{2}\right)$ : calcd: 411.9967 ; found: 411.9965 .

2,6-Bis[4-(dimethylsilyl)phenyl]-2,6-diazaheptane (6). Under $\mathrm{N}_{2}$, to a solution of $\mathbf{1 0}(0.21 \mathrm{~g}, 0.5 \mathrm{mmol})$ in THF $(30 \mathrm{~mL})$ cooled at $-78{ }^{\circ} \mathrm{C}$ was added slowly ${ }^{n} \mathrm{BuLi}(1.2 \mathrm{~mL}$ of $2.5 \mathrm{M}$ in pentane, $3.0 \mathrm{mmol})$. After stirred for $1 \mathrm{~h}$ at $-78^{\circ} \mathrm{C}$, chlorodimethylsilane $(1.0 \mathrm{~mL}, 3.0 \mathrm{mmol})$ was added, and the mixture was gradually warmed to rt, continued stirring for $3 \mathrm{~h}$, and quenched with $\mathrm{H}_{2} \mathrm{O}$ $(5.0 \mathrm{~mL})$. The aqueous layer was extracted with $\mathrm{Et}_{2} \mathrm{O}(3 \times 30 \mathrm{~mL})$, and the organic layer was washed with brine $(30 \mathrm{~mL})$, dried $\left(\mathrm{MgSO}_{4}\right)$, filtered, and evaporated in vacuo. The residue was chromatographed on silica gel (hexane) to give $6(0.16 \mathrm{~g}, 85 \%)$. IR (KBr): v 3443, 2942, 2104, 1634, 1598, 1507, 1377, 1246, 1205, $1107,1009,878,829,800,760 \mathrm{~cm}^{-1} .{ }^{1} \mathrm{H}$ NMR (400 MHz, $\left.\mathrm{CDCl}_{3}\right)$ : $\delta 0.36(\mathrm{~d}, J=3.6 \mathrm{~Hz}, 12 \mathrm{H}), 1.93$ (quint, $J=7.2 \mathrm{~Hz}, 2 \mathrm{H}), 2.98$ (s, $6 \mathrm{H}), 3.42$ (t, $J=7.2 \mathrm{~Hz}, 4 \mathrm{H}), 4.43-4.45(\mathrm{~m}, 2 \mathrm{H}), 6.74$ (d, $J$ $=8.4 \mathrm{~Hz}, 4 \mathrm{H}), 7.43(\mathrm{~d}, J=8.4 \mathrm{~Hz}, 4 \mathrm{H}) .{ }^{13} \mathrm{C} \mathrm{NMR}(100 \mathrm{MHz}$, $\left.\mathrm{CDCl}_{3}\right): \delta-2.8,24.7,38.5,50.3,111.5,121.8,134.7,149.3$. HRMS $\left(\mathrm{FAB}^{+}\right)\left(\mathrm{C}_{21} \mathrm{H}_{34} \mathrm{~N}_{2} \mathrm{Si}_{2}\right)$ : calcd: 370.2261 ; found: 370.2260 .

4-Bromo-4'-iodo-trans-stilbene (13). A mixture of 12 (4.5 g, $18.1 \mathrm{mmol})$ and $\mathrm{P}(\mathrm{OEt})_{3}(3.7 \mathrm{~mL}, 21.7 \mathrm{mmol})$ was refluxed under $\mathrm{N}_{2}$ for $3 \mathrm{~h}$ and then cooled to rt. DMF $(50 \mathrm{~mL})$ was added and then cooled to $0{ }^{\circ} \mathrm{C}$. After stirred for $0.5 \mathrm{~h}$ at $0{ }^{\circ} \mathrm{C}, \mathrm{NaH}(1.1 \mathrm{~g}$, $27.2 \mathrm{mmol}$ ) was added, and the mixture was continued stirring for 0.5 h. Compound 11 (4.2 g, $18.1 \mathrm{mmol})$ in DMF (10 mL) was added, and the mixture was gradually warmed to $\mathrm{rt}$, continued stirring for $5 \mathrm{~h}$, and the mixture was poured into $\mathrm{H}_{2} \mathrm{O}$. The precipitate was collected and washed with $\mathrm{MeOH}$ to give $\mathbf{1 3}$ as a white solid (5.14 g, 84\%); mp 237-238 ${ }^{\circ} \mathrm{C}$. IR (KBr): $v$ 3077, 3040, 3007, 2917, 1961, 1908, 1483, 1405, 972, 821, $715 \mathrm{~cm}^{-1} .{ }^{1} \mathrm{H}$ NMR $\left(400 \mathrm{MHz}, \mathrm{CDCl}_{3}\right.$ ): $\delta 7.02$ (AB quartet, $J=16.6 \mathrm{~Hz}, 16.6 \mathrm{~Hz}, 2$ H), $7.24(\mathrm{~d}, J=8.4 \mathrm{~Hz}, 2 \mathrm{H}), 7.36(\mathrm{~d}, J=8.6 \mathrm{~Hz}, 2 \mathrm{H}), 7.48$ (d, $J=8.6 \mathrm{~Hz}, 2 \mathrm{H}), 7.68(\mathrm{~d}, J=8.4 \mathrm{~Hz}, 2 \mathrm{H}) .{ }^{13} \mathrm{C} \mathrm{NMR}(100 \mathrm{MHz}$, $\left.\mathrm{CDCl}_{3}\right): \delta 93.0,121.4,126.7,127.5,127.7,127.8,131.5,135.4$, 136.1, 137.4. HRMS (FAB $\left.{ }^{+}\right)\left(\mathrm{M}^{+}, \mathrm{C}_{14} \mathrm{H}_{10}{ }^{79} \mathrm{BrI}\right)$ calcd: 383.9011; 

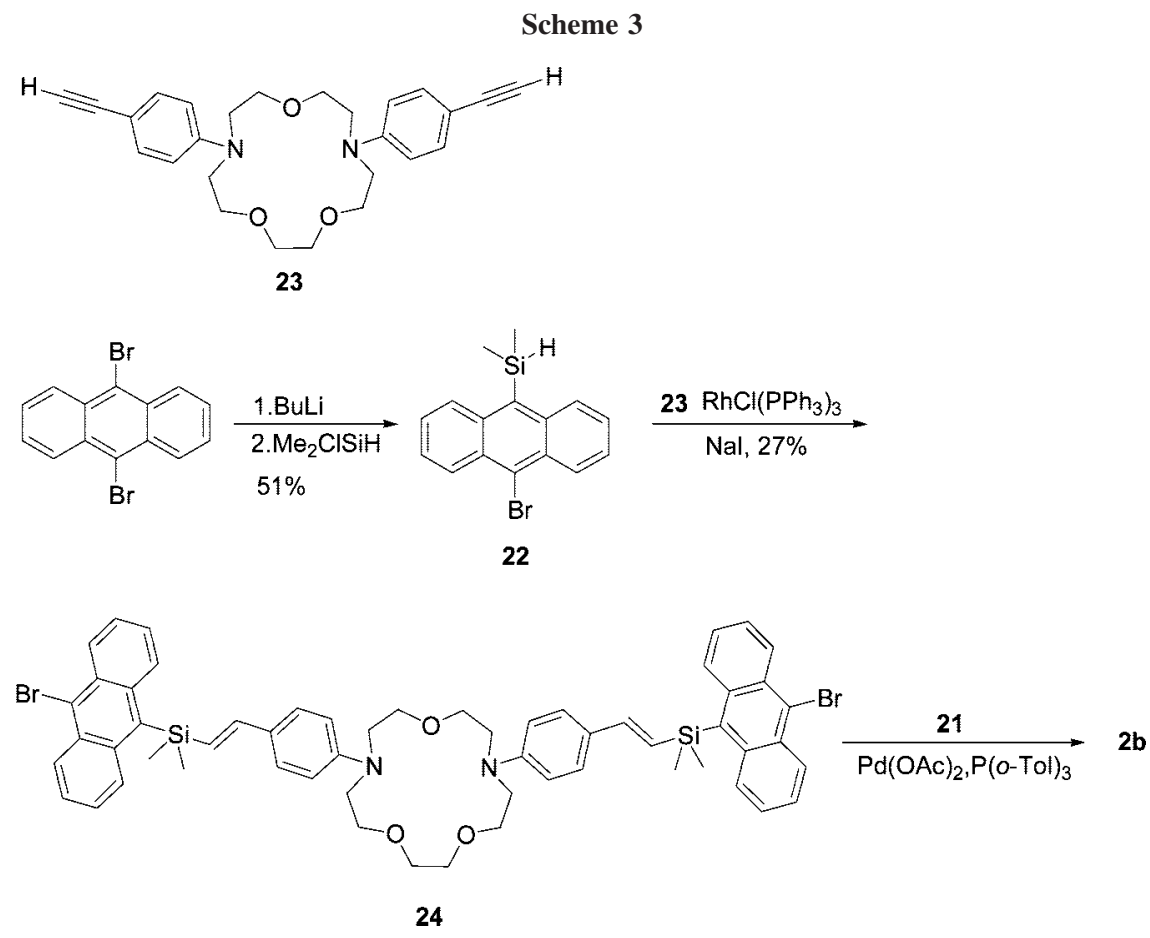

found: 383.9002. Anal. Calcd for $\mathrm{C}_{14} \mathrm{H}_{10} \mathrm{BrI}$ : C, 43.67; H, 2.62; found: $\mathrm{C}, 43.14 ; \mathrm{H}, 2.81$

4-Bromo-4'-[2-(triisopropylsilyl)ethynyl]-trans-stilbene (14). A mixture of $\mathbf{1 3}$ (3.85 g, $10.0 \mathrm{mmol})$, (triisopropylsilyl)acetylene (2.5 mL, $11.0 \mathrm{mmol}), \mathrm{Pd}\left(\mathrm{PPh}_{3}\right)_{2} \mathrm{Cl}_{2}(0.35 \mathrm{~g}, 0.5 \mathrm{mmol})$, and $\mathrm{CuI}$ (95 mg, $0.5 \mathrm{mmol})$ in $\mathrm{NEt}_{3}(40 \mathrm{~mL})$ was refluxed under $\mathrm{N}_{2}$ for $18 \mathrm{~h}$ and then cooled to rt. The mixture was filtered, and $\mathrm{NEt}_{3}$ was evaporated. The crude product was chromatographed on silica gel $\left(\mathrm{CH}_{2} \mathrm{Cl}_{2} /\right.$ hexane $\left.=1 / 5\right)$ to give $\mathbf{1 4}$ as a white solid $(3.74 \mathrm{~g}, 85 \%)$; mp 68-69 ${ }^{\circ} \mathrm{C}$. IR (KBr): $v$ 2942, 2889, 2864, 2153, 1601, 1458, 1074, 968, 882, 833, $670 \mathrm{~cm}^{-1} .{ }^{1} \mathrm{H}$ NMR (400 MHz, $\left.\mathrm{CDCl}_{3}\right): \delta$ $1.15(\mathrm{~s}, 21 \mathrm{H}), 7.05(\mathrm{AB}$ quartet, $J=16.6 \mathrm{~Hz}, 16.6 \mathrm{~Hz}, 2 \mathrm{H})$, 7.36-7.49 (m, 8 H). ${ }^{13} \mathrm{C}$ NMR $\left(100 \mathrm{MHz}, \mathrm{CDCl}_{3}\right): \delta 11.8,19.1$, 91.6, 106.8, 121.3, 122.5, 125.9, 127.6, 127.8, 128.3, 131.4, 132.0, 135.6, 136.4. HRMS $\left(\mathrm{FAB}^{+}\right)\left(\mathrm{M}^{+}, \mathrm{C}_{25} \mathrm{H}_{31}{ }^{79} \mathrm{BrSi}\right)$ calcd: 438.1378; found: 438.1374. Anal. Calcd for $\mathrm{C}_{25} \mathrm{H}_{31} \mathrm{BrSi}$ : C, 68.32; H, 7.11; found: C, 68.90; H, 6.89 .

4-[2-(Triisopropylsilyl)ethynyl]-4'-[2-(trimethylsilyl)ethynyl]trans-stilbene (15). To a mixture of trimethylsilylacetylene (1.5 $\mathrm{mL}, 7.2 \mathrm{mmol})$ and $\mathbf{1 4}(2.11 \mathrm{~g}, 4.8 \mathrm{mmol})$ in piperidine $(40 \mathrm{~mL})$ was added $\mathrm{Pd}\left(\mathrm{PPh}_{3}\right)_{2} \mathrm{Cl}_{2}(0.1 \mathrm{~g}, 0.14 \mathrm{mmol})$ and $\mathrm{CuI}(30 \mathrm{mg}, 0.15$ mmol). The mixture was refluxed for $12 \mathrm{~h}$ under $\mathrm{N}_{2}$ and then cooled to rt. After filtration, the solvent was evaporated in vacuo, and the residue was chromatographed on silica gel $\left(\mathrm{CH}_{2} \mathrm{Cl}_{2} /\right.$ hexane $\left.=1 / 8\right)$ to afford 15 as a white solid $(1.91 \mathrm{~g}, 87 \%) ; \mathrm{mp} 58-59^{\circ} \mathrm{C}$. IR $(\mathrm{KBr})$ : $v$ 3085, 3029, 2943, 2865, 2893, 2154, 1510, 1463, 1412, 1250, 1233, 1016, 996, 760, 863, $838 \mathrm{~cm}^{-1} .{ }^{1} \mathrm{H}$ NMR (400 MHz, $\left.\mathrm{CDCl}_{3}\right)$ : $\delta 0.29$ (s, $9 \mathrm{H}), 1.16(\mathrm{~s}, 21 \mathrm{H}), 7.07$ (s, $2 \mathrm{H}), 7.43-7.48(\mathrm{~m}, 8 \mathrm{H})$. ${ }^{13} \mathrm{C} \mathrm{NMR}\left(100 \mathrm{MHz}, \mathrm{CDCl}_{3}\right): \delta 0.6,11.8,19.1,91.6,95.1,104.9$, $106.8,122.0,122.5,126.0,127.9,128.3,128.5,131.91,131.98$, 136.5, 136.7. HRMS $\left(\mathrm{FAB}^{+}\right)\left(\mathrm{M}^{+}, \mathrm{C}_{30} \mathrm{H}_{40} \mathrm{Si}_{2}\right)$ calcd: 456.2669; found: 456.2665. Anal. Calcd for $\mathrm{C}_{30} \mathrm{H}_{40} \mathrm{Si}_{2}$ : C, 78.88; H, 8.83; found: $\mathrm{C}, 78.75 ; \mathrm{H}, 8.60$.

4-(2-Ethynyl)-4'-[2-(triisopropylsilyl)ethynyl]-trans-stilbene (16). A mixture of $15(1.60 \mathrm{~g}, 3.5 \mathrm{mmol})$ and $\mathrm{NaOH}(0.14 \mathrm{~g}, 3.5 \mathrm{mmol})$ in $\mathrm{MeOH}(10 \mathrm{~mL})$, and THF $(10 \mathrm{~mL})$ was stirred at $\mathrm{rt}$ for $1 \mathrm{~h}$. After filtration, the solvent was evaporated in vacuo, and the residue was chromatographed on silica gel (hexane) to give $\mathbf{1 6}$ as a white solid (1.09 g, 81\%); mp 88-89 ${ }^{\circ} \mathrm{C}$. IR (KBr): $v$ 3301, 2946, 2864, 2149, 1458, 972, 882, $841 \mathrm{~cm}^{-1} .{ }^{1} \mathrm{H}$ NMR $\left(400 \mathrm{MHz}, \mathrm{CDCl}_{3}\right): \delta$ $1.15(\mathrm{~s}, 21 \mathrm{H}), 3.15(\mathrm{~s}, 1 \mathrm{H}), 7.09(\mathrm{~s}, 2 \mathrm{H}), 7.45-7.48(\mathrm{~m}, 8 \mathrm{H}),{ }^{13} \mathrm{C}$ NMR $\left(100 \mathrm{MHz}, \mathrm{CDCl}_{3}\right): \delta 11.8,19.1,78.0,83.6,91.7,106.8$, $120.9,122.5,125.97,126.03,128.1,128.7,131.96,132.05,136.4$,
137.0. HRMS $\left(\mathrm{FAB}^{+}\right)\left(\mathrm{M}^{+}, \mathrm{C}_{27} \mathrm{H}_{33} \mathrm{Si}\right)$ calcd: 385.2352; found: 385.2348. Anal. Calcd for $\mathrm{C}_{27} \mathrm{H}_{33} \mathrm{Si}$ : C, 84.31; H, 8.39; found: C, 84.52; H, 8.08.

4,4' -Bis $(E-2$ - (dimethyl $(E-4-(E-4-($ triisopropylsilyl)ethynyl) styryl)styryl)silyl)vinyl)biphenyl (17). Under argon, a mixture of $16(0.72 \mathrm{~g}, 1.86 \mathrm{mmol}), 5(0.30 \mathrm{~g}, 0.93 \mathrm{mmol})$, and $\mathrm{Rh}\left(\mathrm{PPh}_{3}\right)_{3} \mathrm{Cl}$ $(8 \mathrm{mg})$ in THF $(5 \mathrm{~mL})$ was refluxed for $2 \mathrm{~h}$. After cooled to rt, the mixture was poured into $\mathrm{MeOH}(20 \mathrm{~mL})$. The precipitate was collected and recrystallized from hexane to give $17(0.67 \mathrm{~g}, 66 \%)$; $\mathrm{mp} 145-147{ }^{\circ} \mathrm{C}$. IR (KBr): $v$ 3077, 3027, 2958, 2938, 2889, 2864, 2717, 2153, 1908, 1610, 1511, 1462, 1250, 988, 841, $800 \mathrm{~cm}^{-1}$. ${ }^{1} \mathrm{H}$ NMR (400 MHz, $\left.\mathrm{CDCl}_{3}\right): \delta 0.35(\mathrm{~s}, 12 \mathrm{H}), 1.15(\mathrm{~s}, 42 \mathrm{H}), 6.56$ $(\mathrm{d}, J=19.2 \mathrm{~Hz}, 2 \mathrm{H}), 6.57(\mathrm{~d}, J=19.2 \mathrm{~Hz}, 2 \mathrm{H}), 6.96(\mathrm{~d}, J=$ $19.2 \mathrm{~Hz}, 2 \mathrm{H}), 6.99$ (d, $J=19.2 \mathrm{~Hz}, 2 \mathrm{H}), 7.10$ (s, $4 \mathrm{H}), 7.43-7.50$ $(\mathrm{m}, 16 \mathrm{H}), 7.53(\mathrm{~d}, J=8.4 \mathrm{~Hz}, 4 \mathrm{H}), 7.60(\mathrm{~d}, J=8.4 \mathrm{~Hz}, 4 \mathrm{H})$. ${ }^{13} \mathrm{C}$ NMR $\left(100 \mathrm{MHz}, \mathrm{CDCl}_{3}\right): \delta-2.5,11.3,18.7,91.6,107.2,122.6$, $126.2,126.8,126.89,126.95,127.0,127.6,128.0,129.1,132.4$, $136.9,137.26,137.34,137.8,140.2,144.4$. HRMS $\left(\mathrm{FAB}^{+}\right)$ $\left(\mathrm{C}_{74} \mathrm{H}_{90} \mathrm{Si}_{4}\right)$ calcd 1090.6120; found 1090.6141.

4,4'-Bis $(E-2-((E-4-(E-4-e t h y n y l s t y r y l)$ styryl $)$ dimethylsilyl)vinyl)biphenyl (18). To a solution of $17(0.22 \mathrm{~g}, 0.2 \mathrm{mmol})$ in THF $(5 \mathrm{~mL})$ was added dropwise a $1 \mathrm{M}$ solution of TBAF $(0.5$ $\mathrm{mL}, 0.5 \mathrm{mmol})$. The mixture was stirred at $\mathrm{rt}$ for $2.5 \mathrm{~h}$, diluted with water, and extracted with $\mathrm{CH}_{2} \mathrm{Cl}_{2}(2 \times 20 \mathrm{~mL})$. The organic layer was washed with brine $(10 \mathrm{~mL})$ and dried $\left(\mathrm{MgSO}_{4}\right)$. Solvent was removed in vacuo to give a brown solid which was recrystallized from $\mathrm{CHCl}_{3}$ to give $\mathbf{1 8}(0.14 \mathrm{~g}, 90 \%)$; mp $119-120{ }^{\circ} \mathrm{C}$. IR (KBr) $v$ 3285, 3077, 3023, 2987, 2954, 2917, 2848, 1961, 1675, $1605,1381,1250,1095,1046,984,837 \mathrm{~cm}^{-1} .{ }^{1} \mathrm{H}$ NMR $(400 \mathrm{MHz}$, $\left.\mathrm{CDCl}_{3}\right): \delta 0.35(\mathrm{~s}, 12 \mathrm{H}), 3.14(\mathrm{~s}, 2 \mathrm{H}), 6.56(\mathrm{~d}, J=19.2 \mathrm{~Hz}, 2 \mathrm{H})$, $6.57(\mathrm{~d}, J=19.2 \mathrm{~Hz}, 2 \mathrm{H}), 6.96(\mathrm{~d}, J=19.2 \mathrm{~Hz}, 2 \mathrm{H}), 6.99$ (d, $J$ $=19.2 \mathrm{~Hz}, 2 \mathrm{H}), 7.10(\mathrm{~s}, 4 \mathrm{H}), 7.44-7.50(\mathrm{~m}, 16 \mathrm{H}), 7.53(\mathrm{~d}, J=$ $8.6 \mathrm{~Hz}, 4 \mathrm{H}), 7.60(\mathrm{~d}, J=8.6 \mathrm{~Hz}, 4 \mathrm{H}) .{ }^{13} \mathrm{C} \mathrm{NMR}(100 \mathrm{MHz}$, $\left.\mathrm{CDCl}_{3}\right): \delta-2.5,78.0,83.6,120.6,126.2,126.8,126.88,126.94$, 127.0, 127.6, 128.0, 129.1, 132.4, 136.9, 137.27, 137.33, 137.8, 140.2, 144.3. HRMS $\left(\mathrm{FAB}^{+}\right)\left(\mathrm{C}_{56} \mathrm{H}_{51} \mathrm{Si}_{2}\right)$ calcd 779.3529 ; found 779.3545 .

Polymer 2a. A mixture of 6 (111 mg, $0.3 \mathrm{mmol}), \mathbf{1 8}(234 \mathrm{mg}$, $0.3 \mathrm{mmol})$, and $\mathrm{Rh}\left(\mathrm{PPh}_{3}\right)_{3} \mathrm{Cl}(6.9 \mathrm{mg}, 0.0015 \mathrm{mmol})$ in THF (5 $\mathrm{mL}$ ) was refluxed under $\mathrm{N}_{2}$ for $4 \mathrm{~h}$. After cooling to $\mathrm{rt}$, the mixture was poured into $\mathrm{MeOH}$. The precipitate was collected and redissolved in THF and then reprecipitated with $\mathrm{MeOH}$. The product was collected by filtration and washed with $\mathrm{MeOH}(0.276 \mathrm{~g}, 80 \%)$. 
$M_{\mathrm{n}}=7667$; PDI $=2.53$. IR $(\mathrm{KBr}): v 3414,2950,2900,2889$, $1700,1663,1595,1491,1405,1378,1350,1227,1175,1111,1046$, $850 \mathrm{~cm}^{-1} .{ }^{1} \mathrm{H}$ NMR $\left(400 \mathrm{MHz}, \mathrm{CDCl}_{3}\right): \delta 0.25(\mathrm{~s}, 12 \mathrm{H}), 0.39(\mathrm{~s}$, $12 \mathrm{H}), 1.85-1.95(\mathrm{~m}, 2 \mathrm{H}), 2.96(\mathrm{~s}, 6 \mathrm{H}), 3.35-3.42(\mathrm{~m}, 4 \mathrm{H})$, 6.53-6.62 (m, 4 H), 6.62-6.82 (d, 4 H), 6.89-6.97 (m, 4 H), 7.06 (s, $4 \mathrm{H}), 7.44-7.59(\mathrm{~m}, 28 \mathrm{H})$.

4,4'-Bis $\{\boldsymbol{E}$-2-[dimethyl(vinyl)silyl]vinyl $\}$ biphenyl (21). Under nitrogen, a mixture of $\mathbf{1 9}(2.5 \mathrm{~g}, 12.4 \mathrm{mmol})$, chlorodimethylsilane (4.1 $\mathrm{mL}, 37.1 \mathrm{mmol})$, and $\mathrm{Rh}\left(\mathrm{PPh}_{3}\right)_{3} \mathrm{Cl}(400 \mathrm{mg}, 0.43 \mathrm{mmol})$ in THF (25 mL) was refluxed for $8 \mathrm{~h}$. A solution of vinyl Grignard reagent in THF (1 M, $31 \mathrm{~mL})$ was then added dropwise, and the reaction was refluxed for $8 \mathrm{~h}$. After the mixture was cooled to rt, the solvent was evaporated in vacuo. The residue was chromatographed on silica gel (hexane treated with a trace amount of $\mathrm{NEt}_{3}$ ) (1.9 mg, 41\%); mp 103-104 ${ }^{\circ} \mathrm{C}$. IR (KBr): $v$ 3049, 2987, 2953, 1905, 1603, 1492, 1402, 1247, 1005, 988, 944, 838, 785, 756, 685 $\mathrm{cm}^{-1} .{ }^{1} \mathrm{H}$ NMR $\left(400 \mathrm{MHz}, \mathrm{CDCl}_{3}\right): \delta 0.28(\mathrm{~s}, 12 \mathrm{H}), 5.80(\mathrm{dd}, J$ $=20.2 \mathrm{~Hz}, 3.7 \mathrm{~Hz}, 2 \mathrm{H}), 6.06(\mathrm{dd}, J=14.5 \mathrm{~Hz}, 3.7 \mathrm{~Hz}, 2 \mathrm{H}), 6.26$ $(\mathrm{dd}, J=20.2,14.5,2 \mathrm{H}), 6.52(\mathrm{~d}, J=19.1 \mathrm{~Hz}, 2 \mathrm{H}), 6.96(\mathrm{~d}, J=$ $19.1 \mathrm{~Hz}, 2 \mathrm{H}), 7.56(\mathrm{dd}, J=8.1 \mathrm{~Hz}, 30.0 \mathrm{~Hz}, 8 \mathrm{H}) .{ }^{13} \mathrm{C}$ NMR $(100$ $\left.\mathrm{MHz}, \mathrm{CDCl}_{3}\right): \delta-2.9,126.9,127.0,127.4 .132 .4,137.3,138.2$, 140.2, 144.3. MS $m / z$ (rel intensity): $374\left(\mathrm{M}^{+}, 100\right), 347$ (53), 321 (75), 275 (29), 245 (32), 233 (27), 221 (18), 159 (42), 133 (25), 131 (11). HRMS (FAB) $\left(\mathrm{M}^{+}, \mathrm{C}_{24} \mathrm{H}_{30} \mathrm{Si}_{2}\right)$ calcd: 374.1886 ; found: 374.1880 .

(10-Bromoanthracen-9-yl)dimethylsilane (22). A solution of ${ }^{n} \mathrm{BuLi}$ in hexane $(6.0 \mathrm{~mL}$ of $2.5 \mathrm{M}$ solution, $14.9 \mathrm{mmol})$ was added dropwise to a suspension of 9,10-dibromoanthracene $(5.00 \mathrm{~g}, 14.9$ $\mathrm{mmol})$ in $\mathrm{THF}(400 \mathrm{~mL})$ at $-78^{\circ} \mathrm{C}$, and the mixture was stirred at $-78{ }^{\circ} \mathrm{C}$ for $15 \mathrm{~min}$. Chlorodimethylsilane $(2.41 \mathrm{~g}, 25.5 \mathrm{mmol})$ was then added dropwise at $-78^{\circ} \mathrm{C}$. The mixture was allowed to warm gradually to rt and stirred for $8 \mathrm{~h}$. $\mathrm{NaHCO}_{3}$ solution was then added, and the organic layer was separated. The aqueous layer was extracted with ether, and the combined organic solution was dried $\left(\mathrm{MgSO}_{4}\right)$ and evaporated in vacuo to give the residue which was passed through a short column of silica gel (hexane) to furnish 22 $(2.38 \mathrm{~g}, 51 \%)$; $\mathrm{mp} 53-55^{\circ} \mathrm{C}$. IR (KBr): $v$ 3078, 3052, 2952, 2144 , 1607, 1434, 1258, 918, 883, $837 \mathrm{~cm}^{-1}$. ${ }^{1} \mathrm{H}$ NMR $(400 \mathrm{MHz}$, $\left.\mathrm{CDCl}_{3}\right): \delta 0.71(\mathrm{~d}, J=4.0 \mathrm{~Hz}, 6 \mathrm{H}), 5.49(\mathrm{~m}, 1 \mathrm{H}), 7.52-7.64(\mathrm{~m}$, $4 \mathrm{H}), 8.55-8.68(\mathrm{~m}, 4 \mathrm{H}) .{ }^{13} \mathrm{C}$ NMR $\left(100 \mathrm{MHz}, \mathrm{CDCl}_{3}\right): \delta-1.4$, $125.5,126.5,127.0,128.6,128.9,130.1,134.3,137.4$. MS $m / z$ (rel intensity): $314\left(\mathrm{M}^{+}, 58\right), 316$ (58), 256 (100), 178 (37). HRMS (FAB) $\left(\mathrm{M}^{+}, \mathrm{C}_{16} \mathrm{H}_{15}{ }^{79} \mathrm{BrSi}\right)$ : calcd: 314.0126; found: 314.0128 .

7,13-Bis(4-\{2-[(10-bromoanthracen-9-yl)dimethylsilyl]vinyl $\}$ phenyl)-1,4,10-trioxa-7,13-diazacyclopentadecane (24). Under nitrogen, a mixture of $\mathbf{2 3}(1.25 \mathrm{~g}, 3.0 \mathrm{mmol}), \mathbf{2 2}(1.89 \mathrm{~g}, 6.0 \mathrm{mmol})$, $\mathrm{Rh}\left(\mathrm{PPh}_{3}\right)_{3} \mathrm{Cl}(138 \mathrm{mg})$, and $\mathrm{NaI}(480 \mathrm{mg})$ in THF $(45 \mathrm{~mL})$ was refluxed for $8 \mathrm{~h}$. After cooled it to room temperature, the mixture was poured into $\mathrm{MeOH}$. The precipitate was collected and was chromatographed on silica gel $\left(\mathrm{CHCl}_{3}\right.$ :hexane $=2: 3$ and some $\left.\mathrm{NEt}_{3}\right)$ (0.85 g, 27\%); mp 125-127 ${ }^{\circ} \mathrm{C}$. IR (KBr): v 3020, 2952, 2867, $1602,1515,1434,1385,1350,1552,1184,1124,869,814,750$ $\mathrm{cm}^{-1} .{ }^{1} \mathrm{H}$ NMR $\left(400 \mathrm{MHz}, \mathrm{CDCl}_{3}\right): \delta 0.80(\mathrm{~s}, 12 \mathrm{H}), 3.55-3.70$ $(\mathrm{m}, 16 \mathrm{H}), 3.75-3.77(\mathrm{~m}, 4 \mathrm{H}), 6.65-6.66(\mathrm{~m}, 6 \mathrm{H}), 6.96(\mathrm{~d}, J=$ $18.9 \mathrm{~Hz}, 2 \mathrm{H}), 7.31(\mathrm{~d}, J=8.6 \mathrm{~Hz}, 4 \mathrm{H}), 7.43-7.48(\mathrm{~m}, 4 \mathrm{H})$, $7.52-7.59(\mathrm{~m}, 4 \mathrm{H}), 8.56-8.72(\mathrm{~m}, 8 \mathrm{H}) .{ }^{13} \mathrm{C}$ NMR $(100 \mathrm{MHz}$, $\left.\mathrm{CDCl}_{3}\right): \delta 3.3,51.7,51.9,68.8,70.2,70.8,112.0,124.0,124.8$, $126.4,126.77,126.83,127.8,128.6,129.5,130.2,135.9,137.8$ 143.8, 148.3. MS $m / z$ (rel intensity): $1047\left(\mathrm{M}^{+}+\mathrm{H}, 54\right), 1003$ (48), 1002 (46), 969 (18), 931 (23), 929 (20), 885 (50), 883(22), 859 (8), 739 (80), 737 (100), 709 (12), 690 (20), 664 (13), 628(20), 626 (19), 613 (18), 590 (10), 554 (42), 552 (42), 532 (19), 502 (18). HRMS (FAB) $\left(\mathrm{M}^{+}+\mathrm{H}, \mathrm{C}_{58} \mathrm{H}_{61} \mathrm{~N}_{2} \mathrm{O}_{3}{ }^{79} \mathrm{Br}_{2} \mathrm{Si}_{2}\right)$ : calcd: 1047.2587; found: 1047.2594 .

Polymer 2b. Under nitrogen, a mixture of $\mathbf{2 4}$ (300 mg, 0.29 $\mathrm{mmol}), 21$ (107 $\mathrm{mg}, 0.29 \mathrm{mmol})$, and dried DMF (2.5 mL) in Schlenk flask was added $\mathrm{Pd}(\mathrm{OAc})_{2}(3.0 \mathrm{mg}, 0.04 \mathrm{mmol}), \mathrm{P}(o-\mathrm{Tol})_{3}$ (20.0 $\mathrm{mg}, 0.2 \mathrm{mmol}$ ), and dried $\mathrm{NEt}_{3}(1.0 \mathrm{~mL})$. The mixture was stirred at $70{ }^{\circ} \mathrm{C}$ for $36 \mathrm{~h}$. After cooled it to room temperature, the mixture was poured into $\mathrm{H}_{2} \mathrm{O}$. The precipitate was collected and reprecipitated with $\mathrm{THF}$ and $\mathrm{MeOH}$ for 3 times. Finally, the solid was washed with Hexane. $M_{\mathrm{n}}=3600$; PDI $=1.09$. IR $(\mathrm{KBr}): v$ 3078, 3025, 2939, 2860, 1602, 1515, 1349, 1249, 1182, 1116, 986, $838,815,790 \mathrm{~cm}^{-1} .{ }^{1} \mathrm{H}$ NMR $\left(400 \mathrm{MHz}, \mathrm{CDCl}_{3}\right): \delta 0.50(\mathrm{~s}, 12$ $\mathrm{H}), 0.77(\mathrm{~s}, 12 \mathrm{H}), 3.57-3.76(\mathrm{br}, 20 \mathrm{H}), 6.61-6.74(\mathrm{br}, 6 \mathrm{H})$, $6.91-6.97(\mathrm{~m}, 2 \mathrm{H}), 7.15(\mathrm{~d}, J=19.1 \mathrm{~Hz}, 2 \mathrm{H}), 7.30(\mathrm{~d}, J=8.0$ Hz, 4 H), 7.41-7.52 (br, 8 H), 8.00 (d, $J=19.1 \mathrm{~Hz}, 2 \mathrm{H}), 7.30-7.35$ (br, $4 \mathrm{H}), 7.53-7.56$ (br, $4 \mathrm{H})$.

Acknowledgment. We thank the National Science Council, National Taiwan University, and Shanghai Institute of Organic Chemistry for support.

Supporting Information Available: ${ }^{1} \mathrm{H}$ NMR spectra of all new compounds. This material is available free of charge via the Internet at http://pubs.acs.org.

\section{References and Notes}

(1) Green, B. R.; Parson, W. W. Light-Harvesting Antennas in Photosynthesis; Kluwer Academic: Dordrecht, 2003.

(2) (a) For reviews, see: Wasielewski, M. R. Chem. Rev. 1992, 92, 435. (b) Gust, D.; Moore, T. A.; Moore, A. L. Acc. Chem. Res. 2001, 34 , 40-48. (c) Guldi, D. M. Chem. Soc. Rev. 2002, 31, 22. (d) Guldi, D. M.; Imahori, H. J. Porphyrins Phthalocyanines 2004, 8, 976. (e) Imahori, H. J. Phys. Chem. B 2004, 108, 6130. (f) Imahori, H. Org. Biomol. Chem. 2004, 2, 1425. (g) El-Khously, M. E.; Ito, O.; Smith, P. M.; D'Souza, F. J. Photochem. Photobiol. C 2004, 5, 79. (h) D'Souza, F.; Ito, O. Coord. Chem. Rev. 2005, 249, 1410. (i) Wasielewski, M. R. J. Org. Chem. 2006, 71, 5051.

(3) (a) Stewart, G. M.; Fox, M. A. J. Am. Chem. Soc. 1996, 118, 4354. (b) Devadoss, P.; Moore, J. S. J. Am. Chem. Soc. 1996, 118, 9635. (c) Jiang, D.-L.; Aida, T. Nature (London) 1997, 388, 454. (d) Gilat, S. L.; Adronov, A.; Fréchet, J. M. J. Angew. Chem., Int. Ed 1999, 38, 1422. (e) Plevoets, M.; Vögtle, F.; de Cola, L.; Balzani, V. New J. Chem. 1999, 23, 63. (f) Melinger, J. S.; Pan, Y.; Kleiman, V. D.; Peng, Z.; Davis, B. L.; McMorrow, D.; Lu, M. J. Am. Chem. Soc. 2002, 124, 12002. (g) Liu, D. J.; De Feyter, S.; Cotlet, M.; Stefan, A.; Wiesler, U. M.; Herrmann, A.; Grebel-Koehler, D.; Qu, J. Q.; Mullen, K.; De Schryver, F. C. Macromolecules 2003, 36, 5918. (h) Andrews, D. L.; Bradshaw, D. S. J. Chem. Phys. 2004, 121, 2445. (i) Li, W.-S.; Kim, K. S.; Jiang, D.-L.; Tanaka, H.; Kawai, T.; Kwon, J. H.; Kim, D.; Aida, T. J. Am. Chem. Soc. 2006, 128, 10527.

(4) (a) Nowakowska, M.; Foyle, P. V.; Guillet, J. E. J. Am. Chem. Soc. 1993, 115, 5975. (b) Hisada, K.; Ito, S.; Yamamoto, M. Langmuir 1995, 11, 996. (c) Schultze, X.; Serin, J.; Adronov, A.; Fréchet, J. M. J. Chem. Commun. 2001, 1160. (d) Russel, D. M.; Arias, C. A.; Friend, R. H.; Silvia, C.; Ego, C.; Grimsdale, A. C.; Müllen, K. Appl. Phys. Lett. 2002, 80, 2204. (e) Ohkita, H.; Benten, H.; Anada, A.; Noguchi, H.; Kido, N.; Ito, S.; Yamamoto, M. Phys. Chem. Chem. Phys. 2004, 6, 3977.

(5) (a) Cheng, Y.-J.; Hwu, T.-Y.; Hsu, J.-H.; Luh, T.-Y. Chem. Commun. 2002, 1978. (b) Cheng, Y.-J.; Liang, H.; Luh, T.-Y. Macromolecules 2003, 36, 5912. (c) Cheng, Y.-J.; Luh, T.-Y. Chem.-Eur. J. 2004, 10, 5361. (d) Cheng, Y.-J.; Luh, T.-Y. Macromolecules 2005, 38, 4563. (e) Cheng, Y.-J.; Basu, S.; Luo, S.-J.; Luh, T.-Y. Macromolecules 2005, 38, 1442. (f) Wang, H.-W.; Cheng, Y.-J.; Chen, C.-H.; Lim, T.-S.; Fann, W.; Lin, C.-L.; Chang, Y.-P.; Lin, K.-C.; Luh, T.-Y. Macromolecules 2007, 40, 2666. (g) Yeh, M.-Y.; Lin, H. C.; Lee, S. L.; Chen, C.-h.; Lim, T.-S.; Fann, W.; Luh, T.-Y. Chem. Commun. 2007, 3459. (h) Yeh, M.-Y.; Lin, H.-C.; Lee, S. L.; Chen, C.-h.; Lim, T.-S.; Fann, W.; Luh, T.-Y. Macromolecules 2007, 40, 9238. (i) For a review, see: Luh, T.-Y.; Cheng, Y.-J. Chem. Commun. 2006, 4669.

(6) (a) Morita, T.; Kim, S.; Imanasi, Y. Langmuir 1998, 14, 171. (b) Matsui, J.; Mitsuishi, M.; Miyashita, T. Macromolecules 1999, 32, 381. (c) Dutton, P. J.; Conte, L. Langmuir 1999, 15, 613. (d) Krebs, F. C.; Spanggaard, H.; Rozlosnik, N.; Larsen, N. B.; Jorgensen, M. Langmuir 2003, 19, 7873. (e) Imahori, H.; Hosomizu, K.; Mori, Y.; Sato, T.; Ahn, T. K.; Kim, S. K.; Kim, D.; Nishimura, Y.; Yamazaki, I.; Ishii, H.; Hotta, H.; Matano, Y. J. Phys. Chem. B 2004, 108, 5018.

(7) (a) Chrisstoffels, L. A. J.; Adronov, A.; Fréchet, J. M. J. Angew Chem., Int. Ed. 2000, 39, 2163. (b) Imahori, H.; Kashiwagi, Y.; Hanada, T.; Endo, Y.; Nishimura, Y.; Yamazaki, I.; Fukuzumi, S. J. Mater. Chem. 2003, 13, 2890. (c) Imahori, H.; Sekiguchi, Y.; Kashiwagi, Y.; Sato, T.; Araki, Y.; Ito, O.; Yamada, H.; Fukuzumi, S. Chem.-Eur. J. 2004, 10,3184

(8) (a) Charreyre, M.-T.; Yekta, A.; Winnik, M. A.; Delai, T.; Pichot, C. Langmuir 1995, 11, 2423. (b) Caruso, F.; Donath, E.; Mowhald, H. J. Phys. Chem. B 1998, 102, 2011. (c) Li, Y.; Kuwabara, H.; Gong, Y. K.; Takaki, Y.; Nakashima, K. J. Photochem. Photobiol. B 2003, $70,171$. 
(9) (a) Ajayyaghosh, A.; George, S. J.; Praveen, V. K. Angew. Chem., Int. Ed. 2003, 42, 333. (b) Rau, S.; Schafer, B.; Schebesta, S.; Grussing, A.; Poppitz, W.; Walther, D.; Duati, M.; Browne, W. R.; Vos, J. G. Eur. J. Inorg. Chem. 2003, 8, 1503.

(10) (a) Chen, C.-H.; Liu, K.-Y.; Sudhakar, S.; Lim, T.-S.; Fann, W.; Hsu, C.-P.; Luh, T.-Y. J. Phys. Chem. B 2005, 109, 17887. (b) Lin, C -L.; Yeh, M.-Y.; Chen, C.-H.; Sudhakar, S.; Luo, S.-J.; Hsu, Y.-C.; Huang, C.-Y.; Ho, K.-C.; Luh, T.-Y. Chem. Mater. 2006, 18, 4157.

(11) (a) Kuciauskas, D.; Liddell, P. A.; Lin, S.; Johnson, T. E.; Weghorn, S. J.; Lindsey, J. S.; Moore, A. L.; Moore, T. A.; Gust, D. J. Am. Chem. Soc. 1999, 121, 8604. (b) Tamaki, K.; Imahori, H.; Nishimura, Y.; Yamazaki, I.; Sakata, Y. Chem Commun. 1999, 625. (c) Luo, C.; Guldi, D. M.; Imahori, H.; Tamaki, K.; Sakata, Y. J. Am. Chem. Soc. 2000, 122, 6535. (d) Kodis, G.; Liddell, P. A.; de la Garza, L.; Clausen, P. C.; Lindesey, J. S.; Moore, A. L.; Moore, T. A.; Gust, D. J. Phys. Chem. A 2002, 106, 2036. (e) D'Souza, F.; Smith, P. M.; Zandler, M. E.; McCarty, A. L.; Itou, M.; Araki, Y.; Ito, O. J. Am. Chem. Soc. 2004, 126, 7898. (f) Takagi, S.; Eguchi, M.; Tryk, D. A.; Inoue, H Langmuir 2006, 22, 1406. (g) Kodis, G.; Terazono, Y.; Liddell, P. A.; Andreasson, J.; Garg, V.; Hambourger, M.; Moore, T. A.; Moore, A. L.; Gust, D. J. Am. Chem. Soc. 2006, 128, 1818.

(12) Fang, M.-C.; Watanabe, A.; Matsuda, M. Macromolecules 1996, 29, 6807.

(13) (a) For reviews, see: de Silva, A. P.; Gunaratne, H. Q. N.; Gunnlaugsson, T.; Huxley, A. J. M.; McCoy, C. P.; Rademacher, J. T.; Rice, T. E. Chem. Rev. 1997, 97, 1515. (b) Valeur, B.; Leray, I. Coord.
Chem. Rev. 2000, 205, 3. (c) de Silva, A. P.; Fox, D. B.; Huxley, A. J. M.; Moody, T. S. Coord. Chem. Rev. 2000, 205, 41. (d) Gokel, G. W.; Leevy, W. M.; Weber, M. E. Chem. Rev. 2004, 104, 2723.

(14) Lehmkuhl, H.; Mehler, K.; Benn, R.; Rufinska, A.; Schroth, G.; Krüger, C. Chem. Ber. 1984, 117, 389.

(15) Boon, W. R. J. Chem. Soc. 1947, 307.

(16) Grabowski, Z. R.; Rotkiewicz, K. Chem. Rev. 2003, 103, 3899.

(17) The fluorescence lifetime of the corresponding monomer was employed as the standard (ref 18) to estimate the rate constant of the fluorescence decay of chromophores in copolymers 2 . The environment of the chromophore in $\mathbf{2}$ may be different from the corresponding monomer in solution. There is possibility that self-quenching may occur in $\mathbf{2}$ because of folding. However, it is known that intrachain chromophore-chromophore interactions are important only if the persistent length of the conjugated system is relatively short (e.g., divinylbenzene, refs $5 \mathrm{a}$ and $5 \mathrm{~d}$ ). In other words, when the persistent length is long, the emission profiles of the silylene-spaced divinylarene copolymers are very similar to those of the corresponding monomeric chromophores (ref 5d). In this regard, self-quenching might not be important.

(18) (a) Sandanayaka, A. S. D.; Taguri, Y.; Araki, Y.; Ishi-i, T.; Mataka, S.; Ito, O. J. Phys. Chem. B 2005, 109, 22502. (b) Hattori, S.; Ohkubo, K.; Urano, Y.; Sunahara, H.; Nagano, T.; Wada, Y.; Tkachenko, N. V.; Lemmetyinen, H.; Fukuzumi, S, J. Phys. Chem. B 2005, 109, 15368.

MA800089D 